Dissertação de Mestrado

\title{
PADRÕES MACROECOLÓGICOS DE DISPARIDADE MORFOLÓGICA E DISTRIBUIÇÃO DE MASSA DE MAMÍFEROS TERRESTRES
}

MACROECOLOGICAL PATTERNS OF MORPHOLOGICAL DISPARITY AND BODY MASS DISTRIBUTION IN TERRESTRIAL MAMMALS 

Daniel Varajão de Latorre

Padrões Macroecólogicos de Disparidade Morfológica e Distribuição de massa de Mamíferos Terrestres

Macroecological patterns of Morphological Disparity and Body Mass distribution in Terrestrial Mammals

Dissertação apresentada ao Instituto de Biociêcias da Universidade de São Paulo, para a obtenção de Título de Mestre em Ciências, na Área de Ecologia: Ecossistemas terrestres e aquáticos.

Orientador: Prof. Dr. Tiago B. Quental

São Paulo - SP

2015 
Latorre, Daniel Varajão de

Padrões Macroecólogicos de Disparidade Morfológica e Distribuição de massa de Mamíferos Terrestres

70 páginas

Dissertação (Mestrado) - Instituto de Biociêciasda Universidade de São Paulo. Departamento de Ecologia.

1. Mamíferos 2. Disparidade Morfológica 3. Distribuição de Massa

I. Universidade de São Paulo. Instituto de Biociêcias. Departamento de Ecologia.

\section{Comissão Julgadora:}

Prof. Dr. Paulo Inácio Prado

Dr. Fabricio Villalobos

Prof. Dr. Tiago B. Quental 


\section{Agradecimentos}

Ao Tiago por toda a paciência e dedicação durante esses anos de orientação e por ensinar ciência com entusiasmo. Muito obrigado por me encorajar e contribuir para o meu futuro na ciência.

Ao José A. F. Diniz-Filho e ao Paulo R Guimarães Jr pelas excelentes reuniões de comitê.

Ao CNPq pela bolsa de mestrado.

Ao Toshiba pela amizade e pelas discussões.

Ao Mathias pela co-autoria e por ser uma enciclopédia de mamíferos.

Ao Ary por apply(mestrado, by=day, help!).

À Laura e ao Matheus por tornarem o laboratório um lugar normal.

À Anna Penna e ao Thiago Zahn pela monitoria juntos.

Aos meus amigos por estarem sempre próximos.

Aos meus times de futebol por me deixarem jogar.

A toda a minha família, especialmente à Tia Salô e ao Tio Bio por me receberem em Goiânia.

À familia Yoshihara Caldeira Brandt por me receber de braços abertos, em especial à Célia e ao Fernando.

À Dona Neda por ser minha avó em São Paulo.

Gostaria de agradecer especialmente aos meus pais, Hélcio e Bel, por sempre me apoiarem e oferecerem todo o suporte necessário durante a minha vida e formação. À minha irmã pela paciência.

À Dé por todo o carinho, compreensão, por compartilhar e realizar muitos sonhos em comum. Enfim, por ser ser tudo que eu mais amo! 



\section{Contents}

$\begin{array}{ll}\text { List of Figures } & 7\end{array}$

$\begin{array}{ll}\text { List of Tables } & 9\end{array}$

Introdução Geral 11

1 Macroecological patterns of Terrestrial Mammal Disparity 15

1.1 Introduction . . . . . . . . . . . . . . . . . . . . 15

1.2 Methods . . . . . . . . . . . . . . . . . . 19

1.2 .1 Data . . . . . . . . . . . . . . . . . . 19

1.2 .2 Disparity Measures . . . . . . . . . . . . . . . . . . . . 20

1.2 .3 Null Models . . . . . . . . . . . . . . . . . . . . . . . . . . . 21

1.2.4 Megafauna sensitivity analyses . . . . . . . . . . . . . . 22

1.3 Results . . . . . . . . . . . . . . . . . . . 23

1.4 Discussion . . . . . . . . . . . . . . . . . . . . . 31

1.4 .1 Disparity vs. Diversity . . . . . . . . . . . . . . . . . 31

1.4.2 The effect of Biogeographic realms . . . . . . . . . . . . . 34

2 Effect of Quaternary extinctions on Mammalian body mass distribu$\begin{array}{lr}\text { tion on different continents } & 39\end{array}$

2.1 Introduction . . . . . . . . . . . . . . . . . . . . 39

2.2 Materials and Methods . . . . . . . . . . . . . . . . . 41

2.3 Results . . . . . . . . . . . . . . . . . . . . . . 43

2.4 Discussion . . . . . . . . . . . . . . . . . . . . . . 47

2.4.1 Fitting different distributions on current body mass distribution . 47

2.4.2 The effect of Pleistocene extinction . . . . . . . . . . . 50

2.4.3 The Anthropocene projection .............. 53

Discussão Geral

$\begin{array}{ll}\text { Resumo } & 59\end{array}$

$\begin{array}{ll}\text { Abstract } & 61\end{array}$

$\begin{array}{ll}\text { Bibliography } & 63\end{array}$ 



\section{List of Figures}

1.1 Spatial variation of terrestrial Mammal richness conform to the LDG. . . . . . 19

1.2 Regions as delineated by Olson et al. (2001). Red lines show the biogeographic realms used here to define the Regional pool. Colors indicate biomes. Figure by Olson et al. (2001). . . . . . . . . . . . . . . . . . . . . .

1.3 Relation between the four disparity measures and species richness. Each point represents one grid cell that is colored according to its biogeographic realm as represented in the inset map. Gray shades show the 95\% confidence interval calculated sampling random assemblages from Global Pool. A - Range. B MD. C - MNND, note that MNND is in log-scale for visualization purposes only. D - PR. E - Inset map with color legend for points. . . . . . . . . . . .

1.4 Relation between the four disparity measures and species richness for each realm. The shaded polygons show the $95 \%$ confidence interval based on the Regional null model. Rows show: Range, MD, MNND and PR from top to botton. Biogeographic realms are indicated on the top of each column and are color coded as in Figure 1.3. . . . . . . . . . . . . . . . . 25

1.5 Geographic variation of each disparity measure for assemblages of terrestrial mammals in $1^{\circ}$ cells. Color scale placed at the right side of each map. . . . . . 26

1.6 Quartiles of body mass distribution (in $\log _{2}$ scale) in each $1^{\circ}$ cell of a worldwide grid. . . . . . . . . . . . . . . . . . . .

1.7 Evaluation of observed disparity measures for each cell relative to expected values based on 1000 resamplings given the species richness of each cell. Maps on the left column show the comparison of observed disparity measures relative to resamplings from the Regional pool respective to each cell (refer to Figure 1.2 to region definition). Maps on the middle column show the comparison of observed disparity metrics relative to the expectation for the global null model. Maps on the right column show the comparison of null expectation for the global pool and disparity metrics calculated after the removal of species larger than 100kg. . . . . . . . . . . . . . . .

1.8 Polygons showing the expected relation between disparity measures and species richness for the different Regional pools used here. This panels clarify the comparison between different regional expectations since the same polygons are shown in Figure 1.4. A - Range; B - MD; C - MNND; D - PR.

2.1 Histograms showing body mass distribution (in grams - $\log _{10}$ scale) of terrestrial mammals for all species combined (Global) and for species of each continent separately. Colors represent the three time slices considered: Black - species extinct in the late Pleistocene; Gray - extant species in the Holocene that are either threatened or extinct in historical time; Light-gray - extant and not threatened species. . . . . . . . . . . . . . . . . . 
2.2 Histograms of body mass with best fitted model. Each row refers to a different time slice and each column refers to a geographic area. Red and blue lines denote the first and second, respectively, Normal distributions of the mixture model, they are overlaid to distributions that were better described by a bimodal model (see Table 2.2. Black lines denote the Skew Normal distribution when it provided the best fit. . . . . . . . . . . . . . . .

2.3 Changes in body mass distribution between from the Pleistocene to the Anthropocene. The two big panels on the top represent the proportion of species changes in each size bin of 0.2 units, between Pleistocene and Holocene (left) and Holocene and Anthropocene (right). Curves were drawn to clarify the pattern based on a kernel smoothing. Colors represent each geographical area. The six botton panels show the best model fitted to global data and each of the continents. Different line types represent each time slice analysed here. 


\section{List of Tables}

2.1 Species counts per continent for each time slice considered (refer to main text for time slice definitions). . . . . . . . . . . . . . . . . . . . . . . 42

2.2 The two models Skew Normal (SN) and Bimodal (Bimod) where compared through AIC difference $(\triangle \mathrm{AIC})$, this way zero indicate the best model. Differences higher than two where considered significant. Numbers in parentesis are the weight attributed to each model.

2.3 Parameters estimatives for the best model fitted to each continent at three time slices: P - late Pleistocene; H - Holocene; A - Anthropocene. Table A shows parameters of the mixture model: $\mu_{1}$ and $\sigma_{1}^{2}$ describe the first Normal distribution while $a$ is its relative contribution; $\mu_{2}$ and $\sigma_{2}^{2}$ describe the second Normal distribution, which show $1-a$ contribution to the overall pattern. Table B shows estimatives for the Skew Normal distribution parameters Location, Scale and Skew . . . . . . . . . . . . 46 



\section{Introdução Geral}

Entender os fatores que governam a coexistência de espécies é um dos temas de pesquisa mais importantes em Ecologia. Grande ênfase é dada em entender o papel das interações ecológicas, principalmente o papel da competição. Um dos primeiros à abordar esse tema foi Elton (1946). Ele quantificou o número de espécies de um mesmo gênero coexistindo em uma comunidade. Baseado na premissa que espécies filogeneticamente próximas seriam ecologicamente similares (Darwin, 1859), logo teriam um maior potencial de competição, a expectativa seria de que poucas espécies do mesmo gênero coexistiriam em uma comunidade (Elton, 1946). Posteriormente, o trabalho de Hutchinson (1957) alavancou o enfoque em competição ao propor um conceito operacional de nicho, definido como hiper-volume n-dimensional que descreve todas as condições e recursos necessários para uma espécie manter uma população viável. Esta abordagem enfatizou a expectativa de que duas (ou mais) espécies deveriam apresentar nichos substancialmente distintos para coexistirem de maneira estável (MacArthur \& Levins, 1967) e que a competição entre espécies ecologicamente similares poderia levar ao deslocamento de caracteres (Dayan \& Simberloff, 2005) ou à exclusão competitiva (e.g. Connell, 1961).

Uma forma de investigar a prevalência de competição em comunidades seria estudar a relação entre riqueza de espécies e ocupação do espaço de nicho em diferentes assembleias naturais. Sob essa ótica é considerado o espaço de nicho ocupado por todas as espécies de uma assembleia, e portanto tal abordagem demanda uma quantidade de informação substancial nem sempre disponível. Em particular quantificar diretamente o nicho de diversas espécies não é uma tarefa trivial e a solução adotada por diversos ecólogos é utilizar medidas indiretas que supostamente se correlacionam com o nicho das espécies. Medidas morfológicas (Ricklefs \& Miles, 1994), e principalmente tamanho corpóreo (Bonner, 2011), são comumente utilizadas como "proxy" de nicho uma vez que a morfologia, em particular o tamanho do corpo, reflete inúmeras adaptações ao ambiente e à hábitos de vida. Essa abordagem também permite à comparação entre comunidades distintas o que por sua vez possibilita a investigação de uma série questões. Por exemplo, podemos nos perguntar como a variação da riqueza de espécies está relacionada com a mudança na ocupação do morfoespaço. Um aumento na riqueza de espécies pode resultar de uma expansão do morfoespaço total, o que é em geral interpretado como evidência de competição (Ricklefs \& Miles, 1994; Moreno et al., 2006). Por outro lado é possível que comunidades com maior riqueza apresentem um morfoespaço mais densamente ocupado (empacotamento de nichos). Ambos processos podem ocorrer simultaneamente e entender a contribuição relativa de cada um deles se torna extremamente relevante.

De fato paleontólogos utilizam o registro fóssil para investigar como a variação na 
riqueza de espécies de um dado grupo taxonômico está relacionada com diferentes aspectos da ocupação do espaço morfológico (Foote, 1993; Roy \& Foote, 1997). Apesar das limitações inerentes a dados fósseis, essa abordagem permite paleontólogos a inferir se a quantidade de nichos ocupados aumenta antes ou concomitantemente com o aumento da riqueza de espécies, e portanto permite estudar se a riqueza de espécies está acoplada a diversificação de nichos ecológicos em uma escala temporal. Segundo Benton (2015) grande parte dos estudos sugerem que expansão do nicho total ocupado por um grupo precede a sua diversificação de espécies. Os estudos paleontológicos também evidenciam que processos em escalas temporais amplas (p.ex. especiação e extinção) são importantes para compreender como a riqueza de espécies e de ecologias estariam relacionadas. Dada a natureza similar de tempo e espaço, podemos nos perguntar como é a relação entre a variação de riqueza de espécies e de diversidade de nichos ocupados em diferentes lugares (Roy \& Foote, 1997).

De fato alguns autores argumentam que os estudos das interações ecológicas em escala local não incluem importantes processos que geram e mantém a biodiversidade (Ricklefs, 1987). Em ultima instância o número de espécies decorre dos processos de especiação, migração, e extinção. Esses processos influenciam significativamente a composição de espécies das comunidades (Wiens \& Donoghue, 2004), porém são mais facilmente estudados em uma escala espacial de dimensões continentais (Ricklefs, 2008, 2004). Transitar entre escalas é um dos maiores desafios na ecologia (Levin, 1992). Por exemplo, Brown \& Nicoletto (1991) mostraram que comunidades locais de mamíferos da América do Norte apresentam apenas uma (ou poucas) espécie(s) em cada categoria de tamanho. Essa distribuição uniforme de tamanho corpóreo na escala local difere da distribuição regional, que apresenta uma quantidade muito grande de espécies pequenas e poucas espécies grandes. A princípio essa diferença entre escalas sugere que competição na escala local limita a presença de algumas espécies (Brown \& Nicoletto, 1991), porém é possível que uma dada espécie não ocorra em uma comunidade por fatores não relacionados com a competição como por exemplo devido a uma limitação de dispersão (Ricklefs, 1987). Portanto estudos em escalas espaciais amplas podem complementar estudos locais ou mesmo serem integrados em uma abordagem mais informativa, como por exemplo na construção de modelos nulos regionais com intuito de investigar padrões locais (Cornell \& Harrison, 2014).

A macroecologia é um ramo da ecologia que busca descrever os padrões de diversidade de espécies na escala mais ampla possível (toda a biosfera em alguns estudos - Brown \& Maurer, 1989). Desta forma essa abordagem permite que ecólogos naturalmente incluam processos regionais na compreensão de processos ecológicos relevantes para a coexistência de espécies. Por outro lado análises macroecológicas requerem um grande conhecimento prévio do grupo em estudo e uma grande quantidade de dados ecológicos. Nesse sentido, 
mamíferos formam o grupo ideal e não surpreendentemente se tornaram um modelo para estudos macroecológicos (p.ex. Safi et al., 2011; Huang et al., 2012). Os mamíferos estão espalhados por todo o globo, e podem ser encontrados em praticamente todos os habitats existentes (Macdonald, 2009). A maior parte da diversidade é observada em ambientes terrestres, porém alguns grupos invadiram ambientes aquáticos e também houve a evolução do vôo em pelo menos um grupo (morcegos). Além disso, espécies de mamíferos apresentam ecologias muito diversas, incluindo desde pequenos herbívoros até os maiores predadores observados atualmente, e desempenham importantes papeis ecológicos afetando a diversidade de todo o ecossistema (Dirzo et al., 2014). Por fim, temos uma enorme quantidade de dados ecológicos disponíveis, em particular dados de distribuição geográfica (IUCN, 2012) e de tamanho de corpo (Wilman et al., 2014) o que, a princípio, permite a caraterização de praticamente todas espécies de mamíferos em uma ampla escala geográfica.

Apesar do tamanho de corpo parecer uma medida muito simples de ecologia, sabe-se que esta característica está altamente relacionada com diversos aspectos de um organizamo e pode ser utilizado como um "proxy" razoável para ecologia (Bonner, 2011). Cabe ressaltar que informações a respeito do tamanho de corpo também estão disponíveis para espécies extintas. A partir dessas informações sabemos que no final do Pleistoceno (entre 50 a 10 mil anos atrás) os mamíferos passaram por um evento de extinção onde espécies da megafauna (maiores de $44,5 \mathrm{Kg}$ ) foram preferencialmente afetadas, em particular na Austrália e nas Américas (Koch \& Barnosky, 2006).

Nessa dissertação são apresentados dois capítulos que buscam entender a influência de processos regionais na ocupação dos nichos ecológicos de mamíferos terrestres. Em ambos capítulos utilizamos o tamanho de corpo como um "proxy" para o nicho ecológico e descrevemos como o espaço de nicho (morfoespaço) é ocupado tanto para uma assembleia local quanto para um continente como um todo. No primeiro capítulo investigamos a influência regional na relação entre a ocupação do morfoespaço e riqueza de espécies em assembleias locais. Para tal objetivo comparamos o padrão de disparidade morfológica observado em diferentes assembleias locais com expectativas nulas relacionadas a processos de escala global ou regional. No segundo capítulo quantificamos o padrão das distribuições de tamanho corpóreo de mamíferos em diferentes continentes, como esse padrão foi alterado pelas extinções que ocorreram no final Pleistoceno, e quais as possíveis decorrências da perda de espécies ameaçadas de extinção atualmente. 



\section{Chapter 1}

\section{Macroecological patterns of Terrestrial Mammal Disparity}

This chapter is presented in the form of a manuscript, which is currently in preparation to be submitted for publication. Authors: Daniel V. de Latorre and Tiago B. Quental.

\subsection{Introduction}

Biological diversity patterns are the result of processes that operate and can be studied in different scales, both in space and time (Levin, 1992). It has been proposed that the composition of communities is mostly determined by local species interactions (Weiher \& Keddy, 2001) and great emphasis exists on the role of competition on community's assemblage. This scenario assumes a limiting similarity that allows species coexistence (MacArthur \& Levins, 1967). This limiting similarity is determined by the total resource availability (Hurlbert \& Stegen, 2014) and such view was strongly influenced by the niche theory (Hutchinson, 1957). An alternative view comes from the Neutral Theory of Biodiversity (Hubbell, 2001), which suggests that individuals show equivalent probabilities of reproduction, migration and death regardless of species identity. Given that the number of species is ultimately the result of speciation, migration and extinction, these processes generate the regional species pool and the local communities are composed by a random subset of this larger pool. In fact dispersal limitation can lead species (or entire clades) to be absent from communities in which they would successfully establish (Ricklefs, 1987). These dispersal limitations explain differences in species number and composition in different regions with similar environments (see De Vivo \& Carmignotto, 2004, for an example). However there are several convergent patterns for different regions, for example, local diversity varies predictively with respect to environmental conditions, especially temperature and productivity (Currie et al., 2004). The best-known example is the depiction of the Latitudinal Diversity Gradient (LDG Hillebrand, 2004), where latitude is considered a reasonable surrogate of abiotic and biotic effects (Schemske et al., 2009).

Although ecological theories have been evoked to explain the underlying mechanisms that lead to richness patterns across multiple scales, e.g. metabolic theory (Brown et al., 
2004; Brown, 2014), it is clear that evolutionary history affect biodiversity patterns observed today (Wiens \& Donoghue, 2004; Jablonski et al., 2006; Mittelbach et al., 2007; Wiens, 2011). For example, the edaphic and climatic conditions seen in the Indo-Pacific since the end of the Cretaceous are considered the main reasons for its mangrove extreme richness when compared to other mangroves in the world (Ricklefs \& Latham, 1993). Although the most direct way to account for history would be to study biodiversity on a deep time perspective (e.g. Jablonski et al., 2006), history might be indirectly considered by comparisons between local and regional species richness, given that the regional pool reflects the accumulated diversity over time (Cornell \& Harrison, 2014). Under that premise, initial studies have investigated how competition could limit species presence within local assemblages by documenting the relationship between local and regional diversity (Terborgh \& Faaborg, 1980; Cornell, 1985). It has been argued that a linear increase in local and regional richness could be viewed as evidence for unsaturated communities, whereas saturated communities would be expected to level-off local richness with increasing regional richness (Ricklefs, 1987). However the spatial scale definition of "local" and "regional" may limit the extent of those interpretations (Loreau, 2000), and requires the assumption that all species in the pool could have the presence restricted by competition.

Another, perhaps more direct, way to address the spatial-temporal aspects of diversity saturation, would be to investigate the relation between niche space occupation and community richness (e.g. Ricklefs \& O'Rourke, 1975; Ricklefs \& Miles, 1994). Under this perspective, an increase in species richness could be possible either by expanding the total niche space or by packing species with similar niches on the existing total niche space. It is important to note that these two scenarios are not mutually exclusive and that the packing of species may be due to an increase in species similarity (niche overlap), or by narrowing species niches (specialization). One practical limitation of such approach is to characterize the niche of many different species. Given this difficulty, ecologists and evolutionary biologists have pursued such approach by using morphology as surrogates for species ecologies (Ricklefs \& Miles, 1994).

The use of morphology as a proxy for ecology, or more broadly for the species niche, has a long history in paleontology, given the nature of the raw data in the discipline. Paleontologists have explicitly looked at the relationship between taxonomic and morphological richness by measuring how the morphospace of a group is filled as species richness changes through time (Foote, 1997). It now seems quite clear that morphological diversity (hereafter disparity) of a group can be either coupled or decoupled with species richness (Foote, 1992, 1993, 1997; Roy \& Foote, 1997). For example, Blastoidea (an extinct taxon of Equinoderms) showed a considerable increase in species (and genera) richness in the Early Carboniferous when they first radiate, but only a small expansion 
of the morphospace occupation, which continues to increase even when taxonomic diversity declines during the Permian (Foote, 1993). On the other hand, the decline in the number of species of Phacopida (a subclade in Trilobita) is coupled with a decline in morphological disparity, as a consequence of preferential extinction at the borders of the morphospace (Foote, 1993). Given the exchangeable nature of time and space, it is tempting to investigate the relationship between species richness and morphological disparity across different geographical areas (Roy \& Foote, 1997).

It has been reported that several vertebrate communities show an increase of total niche volume coupled with increases in species richness (reviewed in Ricklefs \& Miles, 1994). Also, increases in species richness seem to be unrelated to morphological differences between species (Ricklefs \& Miles, 1994). Taken together, these two patterns suggest that increases in species richness happen at the periphery of the morphospace (Ricklefs \& Miles, 1994). A similar pattern was found for local communities of frugivores bats (Moreno et al., 2006). However, when different guilds of bats are analyzed together (Moreno et al., 2006) or when different spatial scales are compared (Villalobos \& Arita, 2014) the estimated disparity is not different than the null expectation for the observed species richness. Aditionally, no clear relationship was found between shape disparity measures and species richness for Sepiids' (Cephalopoda, Mollusca - Neige, 2003) nor between total morphospace occupation and species diversity for extant Passarine birds of different biogeographic realms (Ricklefs, 2012) or between niche space volume and species richness for moths from 15 sites in Central and North America (Ricklefs, 2009). It is also important to notice that the relationship between species richness and total morphospace is not necessarily linear or simple. Roy et al. (2001) showed that for IndoPacific strombid gastropods (Mollusca), the occupation of total morphospace although initially linearly coupled with an increase in species richness levels-off after moderate levels of species richness. Therefore, it seems that different taxonomic groups, morphological structures and ecological hierarchies might have their own specific relationship between species and morphological richness.

Mammals, the group of interest here, show inconclusive results regarding how communities at different geographical areas accommodate more species. Studying the morphospace occupation of Central and North American mammalian communities, Shepherd (1998) found that body size disparity (measured as mean pairwise distance, see below) is lower in tropical sites and increases with latitude. On the other hand the same study suggests that some tropical areas show more shape variation than expected at random (Shepherd, 1998). Those two results could be interpreted as evidence for fine niche partitioning between similar size species in tropical communities. However, Safi et al. (2011) found that tropical areas show lower functional diversity than would be expected for the observed phylogenetic diversity, thus suggesting higher similarity 
between co-occurring species in the tropics. It is important to note that Huang et al. (2012) cautioned that interpretations based on the relationship between functional and phylogenetic diversity may be problematic since they are strongly correlated. Furthermore, richer areas also show higher functional diversity, which could be seen as evidence for total niche expansion, an aspect not directly addressed by Safi et al. (2011).

Currently there are 5416 recognized species of mammals (Wilson \& Reeder, 2011) that span from tiny $2 \mathrm{~g}$ shrews to enormous 200ton whales. Mammals can be found in virtually every habitat on earth. The vast majority is terrestrial, but there are over 150 species almost exclusively aquatic and more than 1000 are volant (bats). Although representatives of the mammalian Class can be found worldwide, the effect of geography on the diversification of major groups (above and at the Ordinal level) is considerable, resulting in clades evolving separately in different continents (dos Reis et al., 2012). For example, the oldest Marsupials (Metatheria) fossils are from Laurasia (the paleocontinent that was formed by the Neartic and Paleartic biogeographic realm) but, extant species derived from groups restricted to Autralasian and Neotropical realms since late Cretaceous (revised in Springer et al., 2011). In fact the long isolation of Australia after Gondwana separation is responsible for the unique fauna observed in the continent. Australian marsupials greatly diversified and converged to niches occupied by Plancental (Eutheria) orders, in other regions. Eutherian Orders are grouped in Laurasian, Afrotheria and Xernarthra, reflecting the biogeographic region where they originated and evolved. Nevertheless species exchanges between regions are common when continents are connected and those migrations have clearly affected mammal composition on different continents (Woodburne, 2010; Bacon et al., 2015; Mathias M. Pires, 2015, in review). Additional to deep time migrations, the effect of humans in the last 40 thousand years might also alter the current biogeographical distribution of mammal species (Faurby \& Svenning, 2015). The role of humans in the megafauna extinction around 10 thousand years ago is room for a large debate (Koch \& Barnosky, 2006), but the extinction of large species clearly changed ecological communities and species interactions (e.g. Pires et al., 2014). Therefore mammals represent an ideal group to study the effect of regional processes on the relevance of local and regional scales processes on several aspects of how their assemblages are organized.

Here we investigate the effect of geography on the relationship between morphological disparity and species richness of terrestrial non-volant mammal assemblages using body mass as a surrogate for morphology. Although this might seem as a crude proxy, body size is well known to affect many aspects of the life of an organism (Bonner, 2011) and if used with caution can be seen as a first good approximation of general ecology. To study the relationship between morphological and species richness we described the spatial variation of four morphological disparity measures, its relation with species richness and 
compared the observed relation with null expectations from random assemblages. By using this approach we expect to better understand the effect of regional processes on the relation between mammal richness and morphological (ecological) variation.

\subsection{Methods}

\subsubsection{Data}

To measure the spatial variation of morphological disparity we first determined the spatial distribution for all terrestrial mammals. We used terrestrial mammals geographic range maps from the IUCN RedList (IUCN, 2012, downloaded on January/2013) for all available species and determined their presence or absence in every $1^{\circ}$ cells of a world grid on equal area Mollweide projection. Valid cells were assigned as those covered by at least $50 \%$ of land, according to the map provided by Natural Earth (naturalearthdata.com). Species were considered present in a cell if its range touched any fraction of the cell area. The observed richness of cells followed the expected LDG for mammals (Figure 1.1, see also Buckley et al., 2010). Morphological disparity was measured (see below) for the species assemblage of each cell.
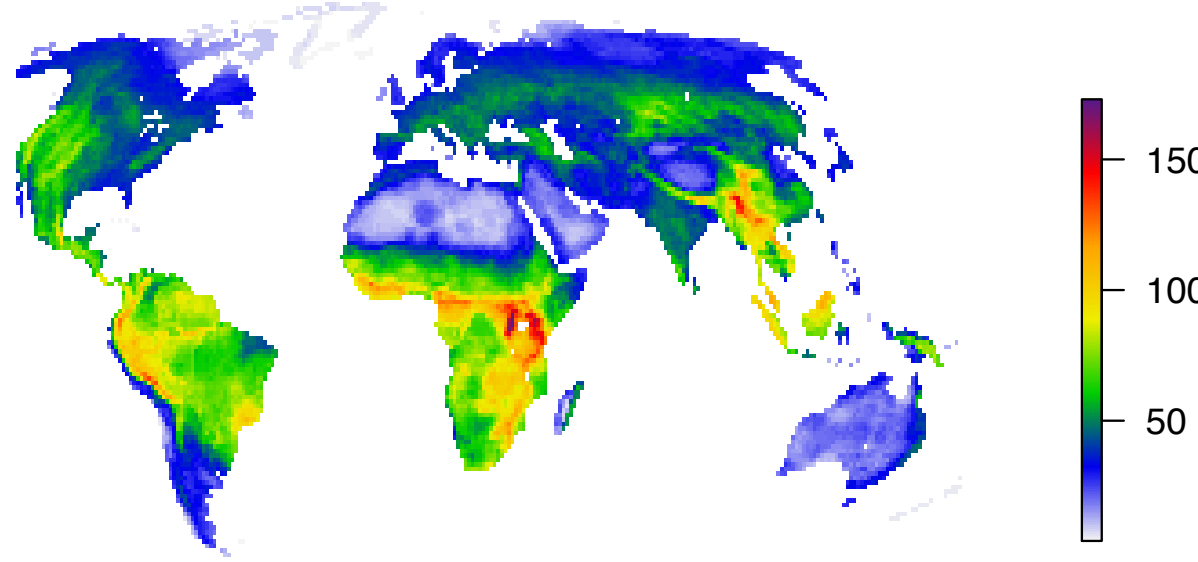

Figure 1.1: Spatial variation of terrestrial Mammal richness conform to the LDG.

Species average body size was used as descriptor of mammalian morphology, since it is a fundamental trait that correlates with the majority of other morphological traits and is relevant for many physiological and ecological adaptations (Bonner, 2011). Given the 
great overlap of body size between bats and other small mammals and the fact that other traits, such as wing size and shape, might be better descriptors of bat ecology (Norberg, 1994) we limited our analysis to terrestrial mammals. In total 4146 terrestrial species were considered in this study.

For mammals, body mass information is available in several organized datasets comprehending almost all species of the Class. We used information for 3824 species provided in the EltonTraits 1.0 dataset (Wilman et al., 2014) with a few corrections that were necessary. Body mass data for 115 species was kindly provided by M. Cianciruso and J.A.F. Diniz-Filho as used in (Safi et al., 2011). The remaining 207 species were analyzed one-by-one, based on the taxonomic notes available in IUCN RedList website and checking if synonyms species could be present in (Wilson \& Reeder, 2011). When a synonymous was found, its body mass value was assigned to the species with missing data. We used body mass values transformed by the logarithm on base two in order to make the comparisons between values proportional.

\subsubsection{Disparity Measures}

To help build a better intuition of spatial variation of body mass we first described six summary statistics for each cell assemblage: 1) minimum; 2) 1st quantile; 3) median; 4) mean; 5) 3rd quantile; and, 6) maximum body mass. Then, for each cell we estimated four disparity measures, namely: Range, Mean pairwise Distance (MD), Mean Nearest Neighbor Distance (MNND) and Participation Ratio (PR). The use of different metrics allows a better understanding of how the morphological space is occupied since different metrics capture different properties of morphospace occupation (Ciampaglio et al., 2001). We considered the Range of body mass values for each assemblage of species as a proxy of the total niche space occupied in that assemblage. However, we should note that Range is very sensible to outliers, and caution should be taken in our interpretations. We also note that an increase of Range could be due to an increase of maximum or a decrease of minimum value, but this can be discriminated by examining the summary values described above. The remaining three disparity measures, Mean pairwise Distance (MD), Mean Nearest Neighbor Distance (MNND) and Participation Ratio (PR) reveal different patterns of morphospace occupation. We computed the Mean pairwise Distance (MD) between species in the morphospace. This measure highly correlates with variance but it is more robust to compare different sample sizes (Foote, 1993; Ciampaglio et al., 2001). In the case of this study the MD shows how spread is the mass distribution of an assemblage. The Mean Nearest Neighbor Distance (MNND) is a metric that has traditionally been used to infer niche packing in community ecology studies. Nearest Neighbors are defined as the closest species in the 
morphospace, in this study defined only by mass. Low values of MNND suggest that species are packed in the morphospace. However as two species are allowed to be each other's Nearest Neighbor, this metric can be biased in a case where species are clumped in distinct groups in the morphospace. The Participation Ratio (PR) measure captures the evenness of body mass distribution for an assemblage in a way similar to the Simpson Index of diversity. To calculate the PR, it is necessary to use discrete intervals of body mass. We considered each order of magnitude, in Log 2 scale, to be a bin. The calculation is given by $\frac{1}{\sum n_{i}^{2} / N^{2}}$. Where $n$ is the proportional number of species present in each bin $(i)$, and $N$ is the total number of species in the assemblage. The PR values vary from 1, when all species are present in the same bin, to the maximum number of bins, when all bins are occupied with the same number of species.

\subsubsection{Null Models}

To compare the observed level of disparity to what would be expected for the species richness seen in each grid cell we constructed two different null models. The main differences between the two null models are the nature and the size of the species pool. The choice of species pool can strongly influence the generated null distribution (Lessard et al., 2012; Cornell \& Harrison, 2014) and represent the expectation of different processes. We therefore decided to use two different pools that try to understand the influence of historical and regional processes in our mammal assemblages. The first pool (Global) includes every species of mammals used in the present study, such that the same species pool is used to define the null expectation for all grid cells. The probability of each species to be sampled depended on the observed area of its distribution (proportion between number of occupied cells by the total of valid cells). This seems to be the most appropriated pool if one is interested on understanding if different large geographical areas have very different properties, likely to be related to historical and evolutionary effects. However ecological effects specific to given continents might also be at play. Therefore we defined the second pool (Regional) restricting species composition by the biogeographic realm, expecting that it would reflect historical contingencies. Biogeographic realms were first defined by (Wallace, 1876), but newer proposals have been made (Holt et al., 2013, but see Kreft \& Jetz, 2013) and are mainly defined by major spatial turnover (beta-diversity) of assemblages. Here we used the common definition of Udvardy (1975) as used by Olson et al. $(2001,1.2)$. There are no valid cells in Oceania (small Pacific islands) and no terrestrial mammals present in Antarctica, thus we ended with 6 biogeographic pools to perform the re-samplings. Each grid cell was assigned to only one biogeographic realm. Grid cells on the border of realms were assigned to the realm that covered most of the cell area. All species that were present in at least one 
cell of a realm were defined as belonging to its pool, and the number of cells a species occupied within the realm weighted its sample probability.

By using two different pools we hope to be able to discuss how historical and regional processes influence the empirical disparity patterns expected for a given species diversity. To build the null distribution of disparity for each focal cell we sampled the same number of observed species from a pool, global or regional, and calculated the four disparity measures for the random assemblage. We repeated this procedure 1000 times and then compared the observed disparity values with the null distributions in order to evaluate if the empirical disparity values departs from the expected random pool for the each disparity metric.

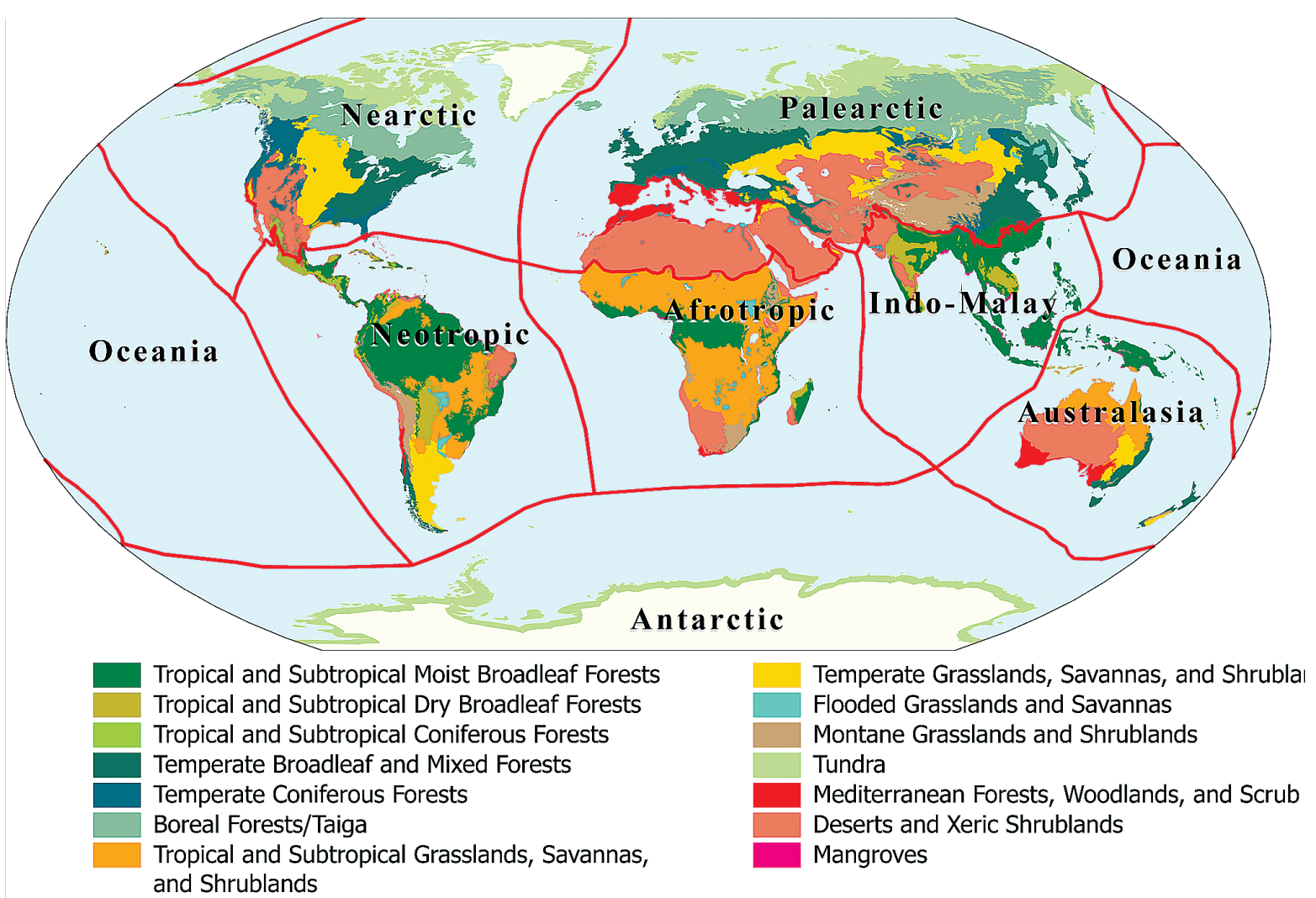

Figure 1.2: Regions as delineated by Olson et al. (2001). Red lines show the biogeographic realms used here to define the Regional pool. Colors indicate biomes. Figure by Olson et al. (2001).

\subsubsection{Megafauna sensitivity analyses}

During the late Pleistocene a biased extinction of large mammals affected all continents, but with different outcomes. Australia, South and North America were the most severely affected since all species larger than $100 \mathrm{Kg}, 320 \mathrm{Kg}$ and $1000 \mathrm{Kg}$ respectively, completely disappeared (Koch \& Barnosky, 2006). Eurasia and Africa also lost part of 
its megafauna but several representatives remained (revised in Koch \& Barnosky, 2006, see also Chapter 2). These extinctions occurred from 50 to 10 thousand years ago (Koch \& Barnosky, 2006) and they could potentially bias our results. To examine the effect of megafauna extinction on our analysis removed all species heavier than $100 \mathrm{Kg}$ from our datasets and re-ran our analysis, i.e. calculated the four disparity measures and compared the observed pattern with the expected from the Global Pool without large species. With this approach we expect to investigate how robust our previous analysis were to this megafauna extinction. Also it allows us to verify if particular patterns of morphospace occupation were mainly driven by differential megafauna extinctions.

\subsection{Results}

Different disparity metrics are not equally related to species richness, and some seem to be more informative than others. At a global scale, the body mass Range rapidly increases with respect to species richness but it quickly levels-off at around 40 to 50 species (Figure 1.3). Although a similar pattern is seen when analyzing most of the continent separately (Figure 1.4), the Australian realm seems to be slightly different (Figure 1.4), since richer cells show values of body mass Range that are smaller than cells with intermediate species richness. When comparing body mass Range between biogeographic realms it is also clear that Africa and Indo-Malay stand out (Figure 1.5). These two realms show the largest values of Range and also the presence of the largest terrestrial mammals in the world (Figure 1.6). Interestingly, if we ignore these realms the rest of the globe seem to conform on a latitudinal gradient of Range from North to South.

The global relationship between MD and richness seems to be uninformative (Figure 1.3B). Although MD does not co-vary with richness, it shows a decreasing variance with increasing diversity. When looking at each realm separately we see a similar relationship between MD and richness, but some realms show a slight tendency of either increase or decrease MD values with respect to species richness. The striking spatial difference on this disparity metric is that South America, and parts of Australia, have considerably smaller values than the other continents (Figure 1.5).

The observed MNND decreases with increasing richness (Figure 1.3C, note that the $\mathrm{y}$-axis is in log scale for visualization purposes), both at the global scale and also when looking at each biogeographic realm separately (Figure 1.4). We should note that this decrease is steep for low values of richness and becomes less prominent for intermediate and high species richness. This is evident once we note the Log scale on the y-axis of Figures 1.3 and 1.4. MNND yielded a spatial pattern where most of the globe shows 

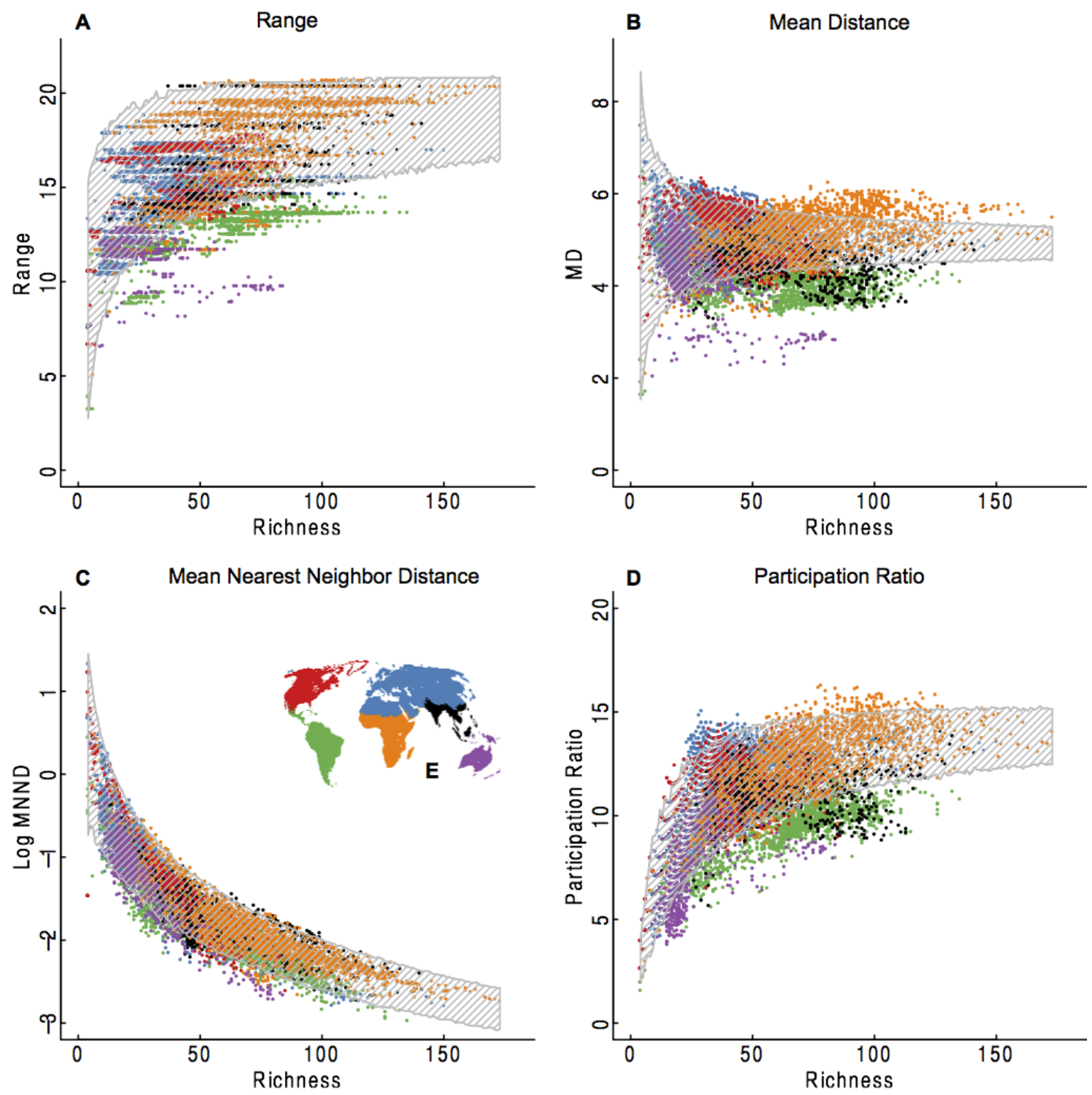

Figure 1.3: Relation between the four disparity measures and species richness. Each point represents one grid cell that is colored according to its biogeographic realm as represented in the inset map. Gray shades show the 95\% confidence interval calculated sampling random assemblages from Global Pool. A - Range. B - MD. C - MNND, note that MNND is in log-scale for visualization purposes only. D - PR. E - Inset map with color legend for points.

values between zero and one (Figure 1.5), except for small areas in Sahara Desert and islands such as Greenland and New Zealand.

The global relationship between PR and species richness is similar to the one observed for Range. The values of PR rapidly increase with species richness but then levels-off at high diversity (Figure 1.3D). A similar relationship is seen for each realm when analyzed separately (Figure 1.4). We should also note that Australia shows the lowest values while Africa shows the highest values, and the remaining estimates seem to roughly conform 

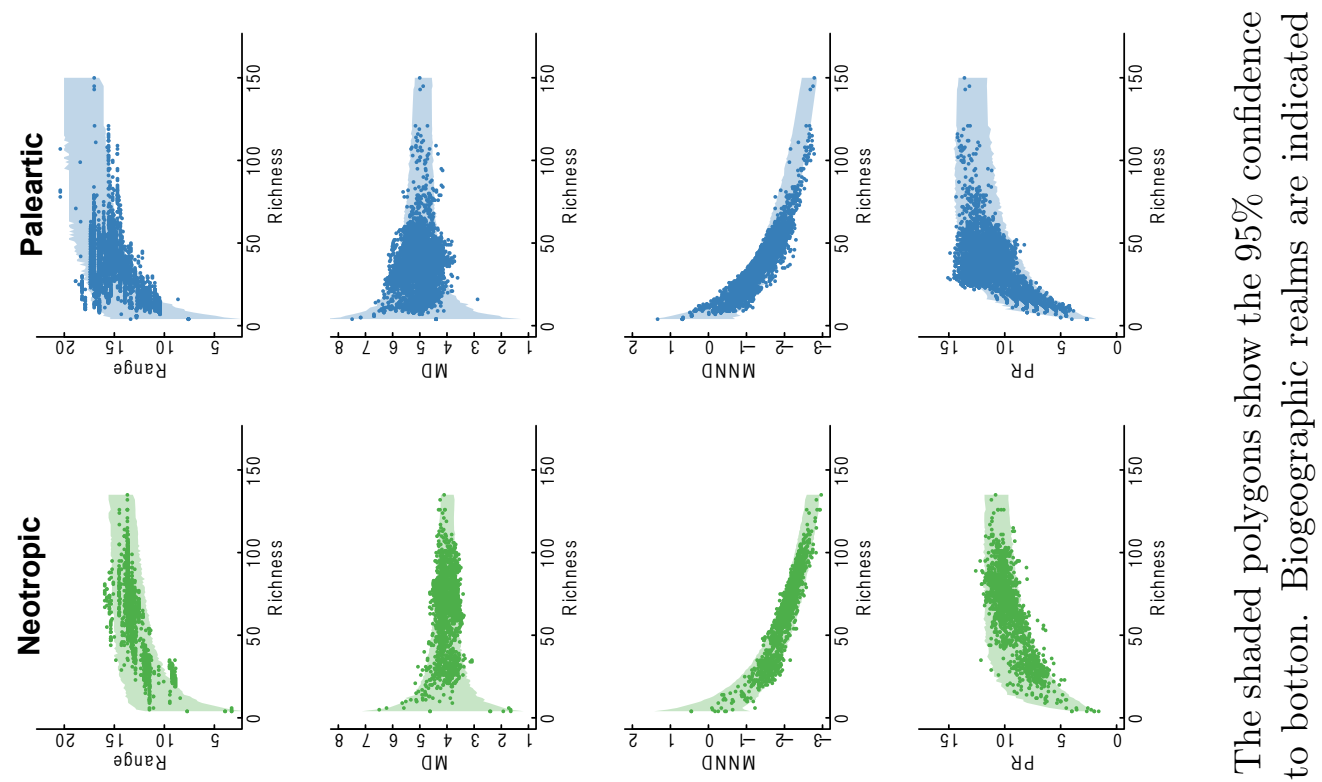

घ
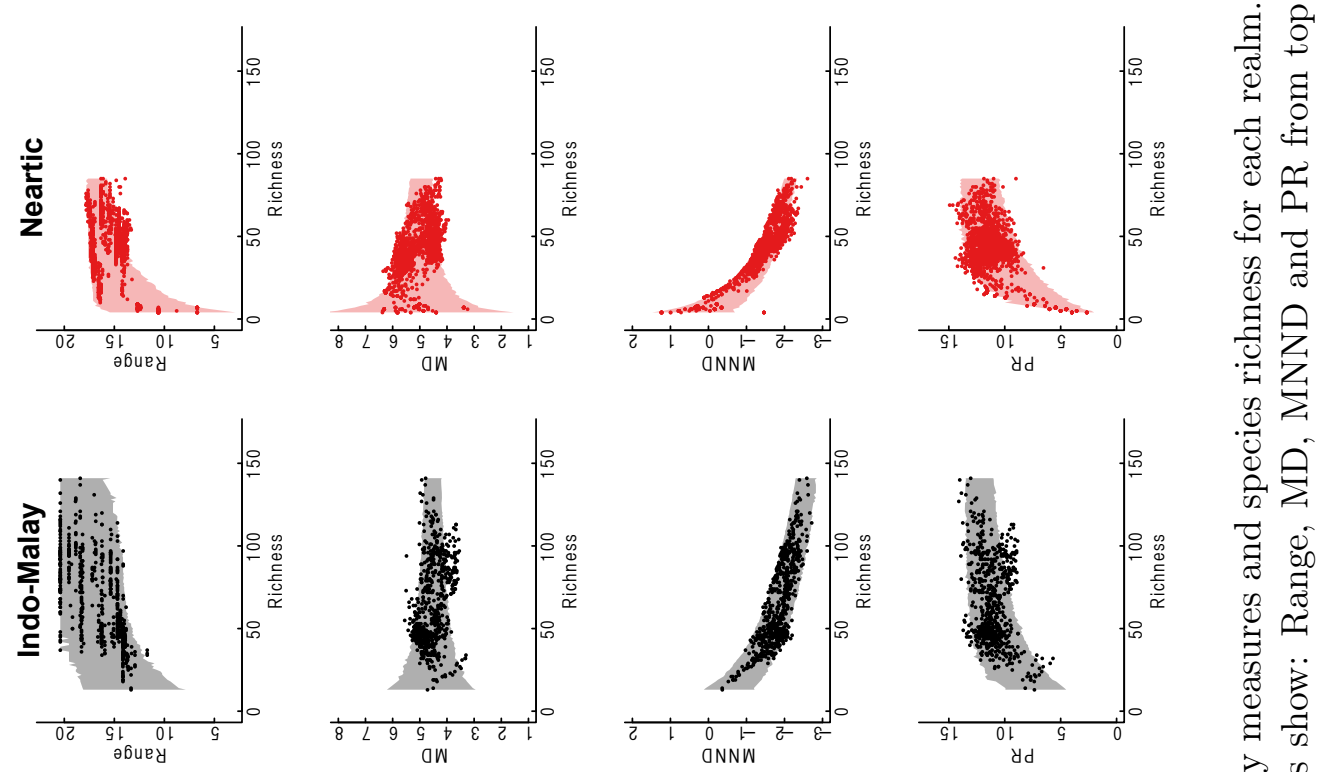

尊是
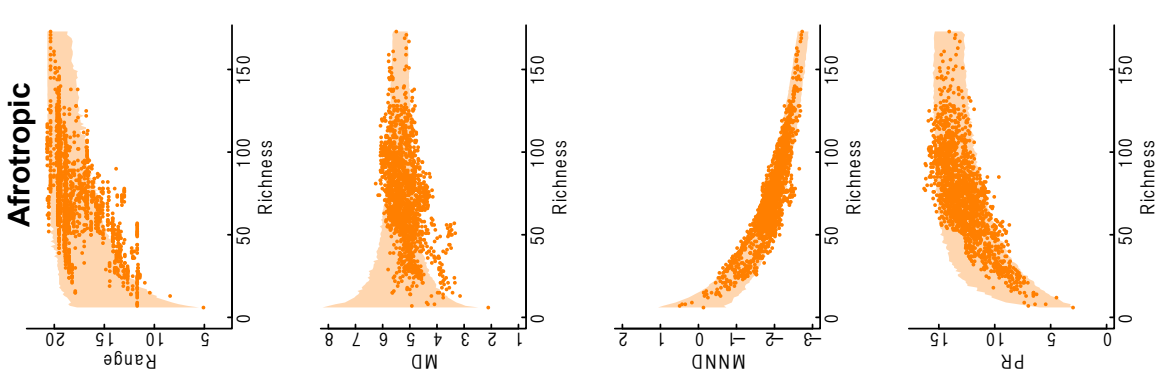

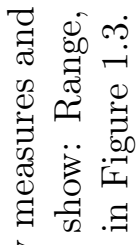

矛的

藏氠

:

పె

站寻

卷
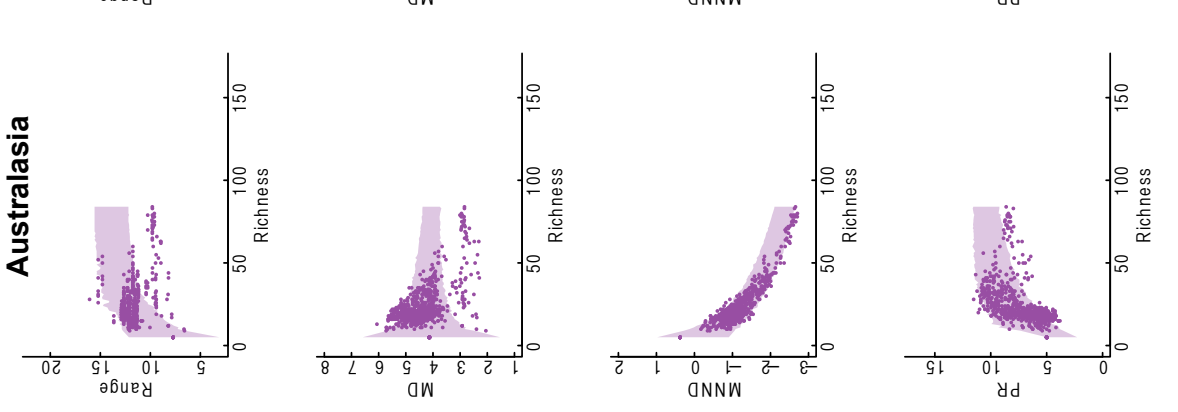

然

의

.웡

离

मे. चु

그

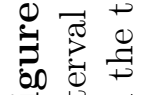

哇. 

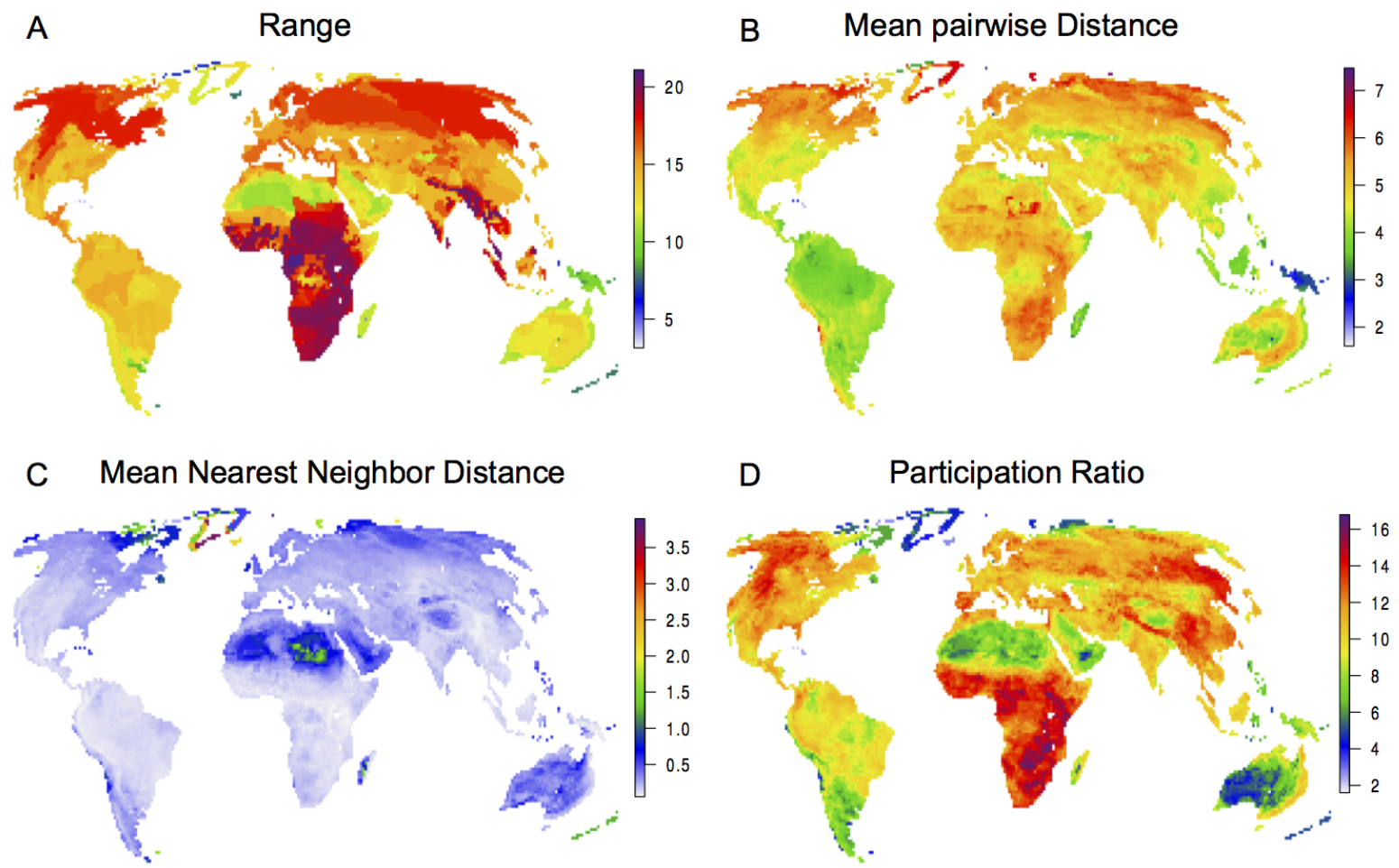

Figure 1.5: Geographic variation of each disparity measure for assemblages of terrestrial mammals in $1^{\circ}$ cells. Color scale placed at the right side of each map.

to a gradient where the Northern hemisphere shows the highest values (except from Greenland) which decrease towards the South (Figure 1.3D). We are aware that these visual inspections on the potential co-variation between different disparity metrics and species richness should be further confirmed with proper statistical analysis but this is beyond our purpose. Here we focus on the observed deviations to the null model expectation, with special attention to comparing the global and regional pools.

When estimates of disparity for each grid cell are compared to the expected distribution of values from the Global null model it is possible to see that some biogeographic realms clearly deviate from the expectation (Figure 1.3). These deviations are either for specific values of species richness (e.g. richer areas of Australian realm), or for most cells of an entire biogeographic realm. Considering all disparity measures, the Neotropics most notably deviates from the global null model (Figure 1.3). This region show low values for all disparity metrics in most of its geographic area (Figure 1.5) and is the region for which the largest continuous area significantly deviates from null expectation of Range, MD and PR (Figure 1.7). These three measures show values that are smaller than expected for the observed richness when random assemblages are drawn from the Global Pool. In fact, the observation of summary information of body mass for each cell (Figure 1.6) already suggests that both the smallest and biggest terrestrial mammals 

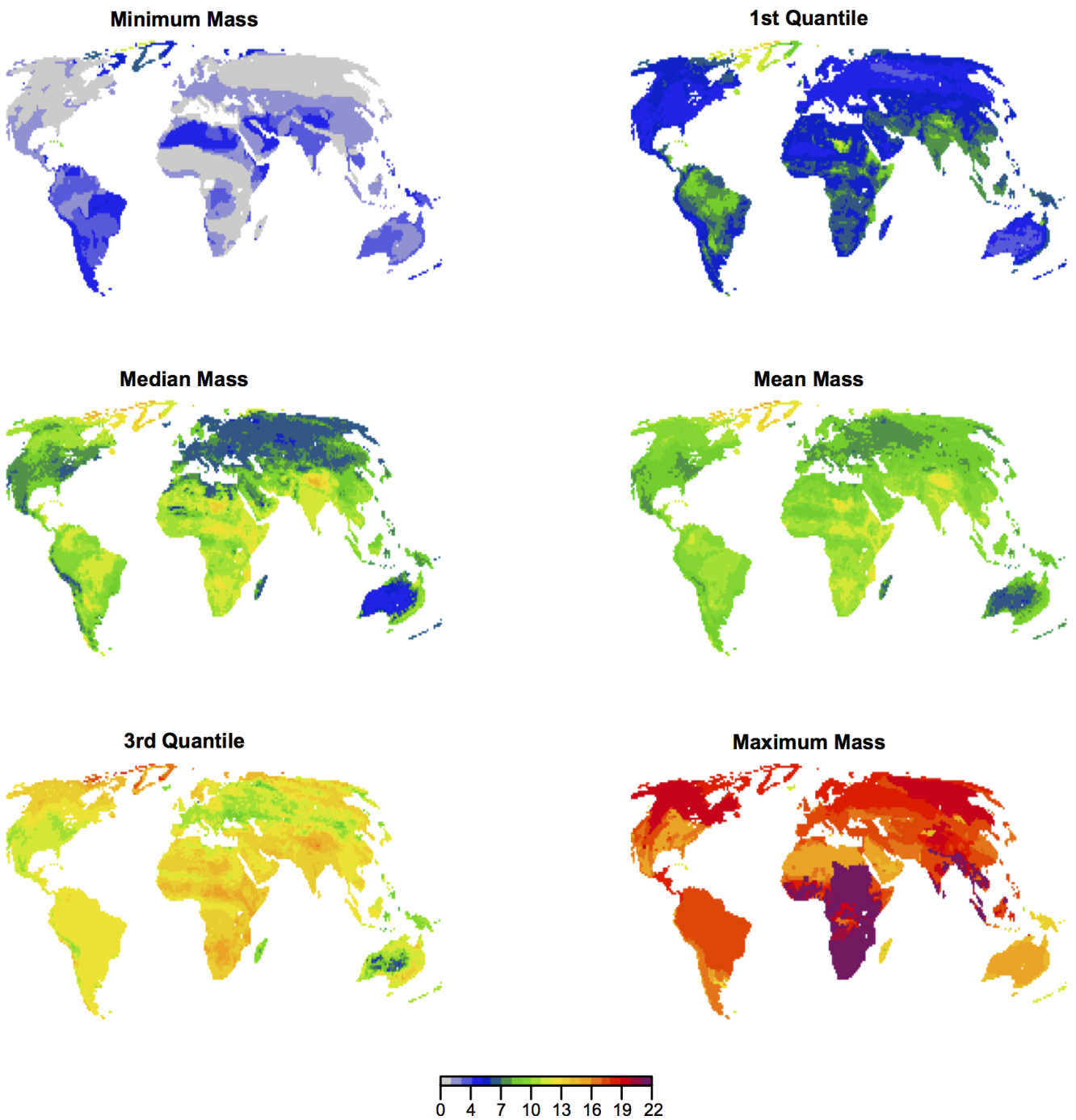

Figure 1.6: Quartiles of body mass distribution (in $\log _{2}$ scale) in each $1^{\circ}$ cell of a worldwide grid.

in the Neotropics are not as small nor as big as the rest of the world, thus different from what would be expected from the Global Pool (Figure 1.7). It is important to note that this striking deviation of Range does not seem to be a sole bias of megafauna preferential extinction during late Pleistocene since the sensitivity analysis (removal of species lager than $100 \mathrm{Kg}$ from the global pool) show similar results. Also, the pattern seen for MD and PR is not affected by the absence of large species (Figure 1.7). Lower than expected MD and PR suggest that the Neotropics have a concentration of certain body sizes with respect to what would be expected by the global pool (Figures 1.3 \& 1.7). This concentration in certain body size values (revealed by lower PR values) and overall similarity among species (revealed by a lower than expected MD) seem to be generated not only by the current absence of small and big species (Figure 1.6), but also from a concentration of intermediate size species (see Chapter 2). When comparing 


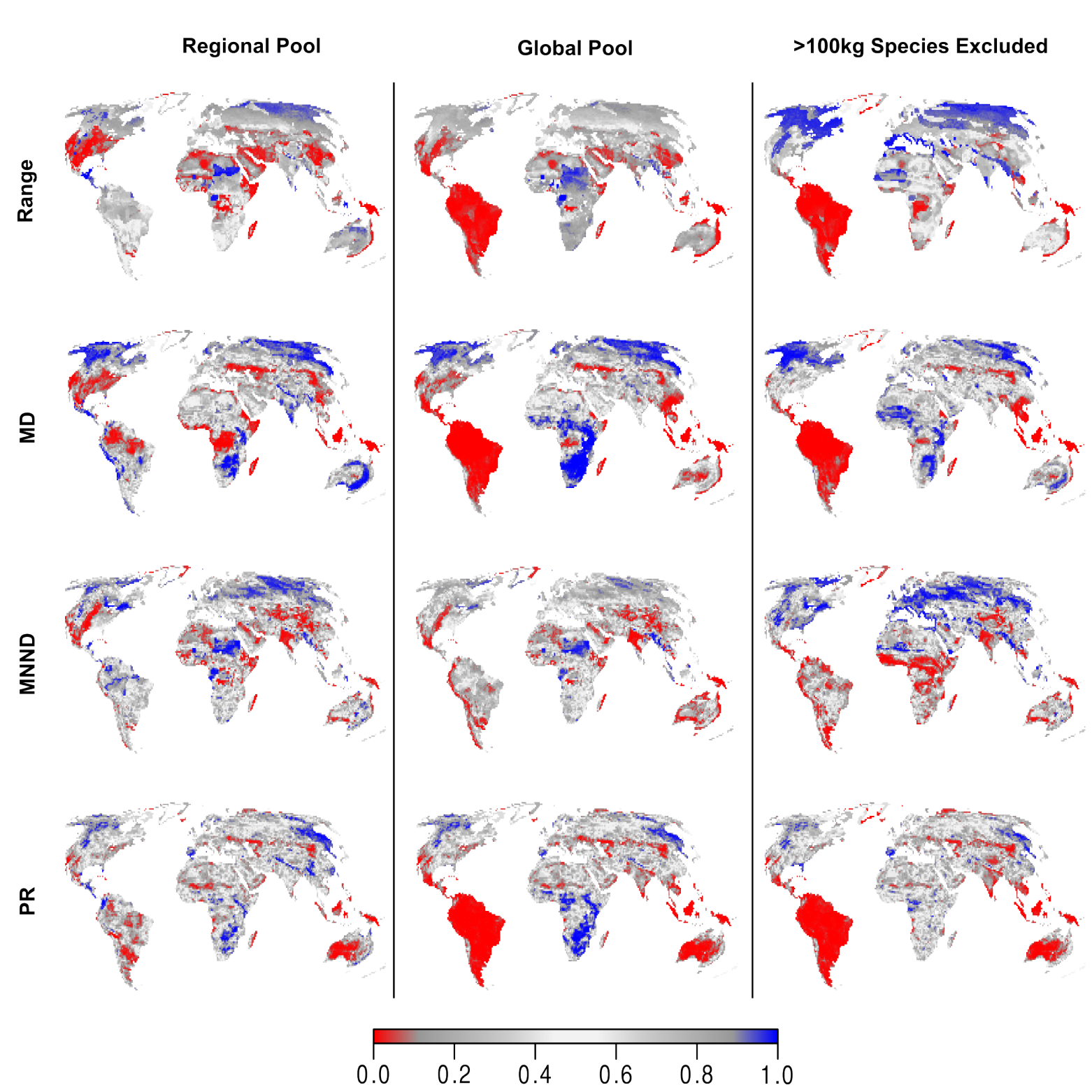

Figure 1.7: Evaluation of observed disparity measures for each cell relative to expected values based on 1000 resamplings given the species richness of each cell. Maps on the left column show the comparison of observed disparity measures relative to resamplings from the Regional pool respective to each cell (refer to Figure 1.2 to region definition). Maps on the middle column show the comparison of observed disparity metrics relative to the expectation for the global null model. Maps on the right column show the comparison of null expectation for the global pool and disparity metrics calculated after the removal of species larger than $100 \mathrm{~kg}$.

Neotropical disparity to the expected disparity given the Regional pool, most cells fall within the confidence interval of the null model. The only spatial pattern that stands out is MD lower than expected in large areas of Amazon forest (Figure 1.7). It is interesting to note that the null expectation for the relations between each disparity metric and species richness have a similar shape to the expected by the Global Pool (described above), but differences between biogeographic realms arise (Figure 1.8). These differ- 
ences are easier to observe for higher levels of species richness. This observation shows that differences arise even for random assemblages drawn from distinct pools and that Neotropic lower disparity seems to be a pattern expected for the entire realm.
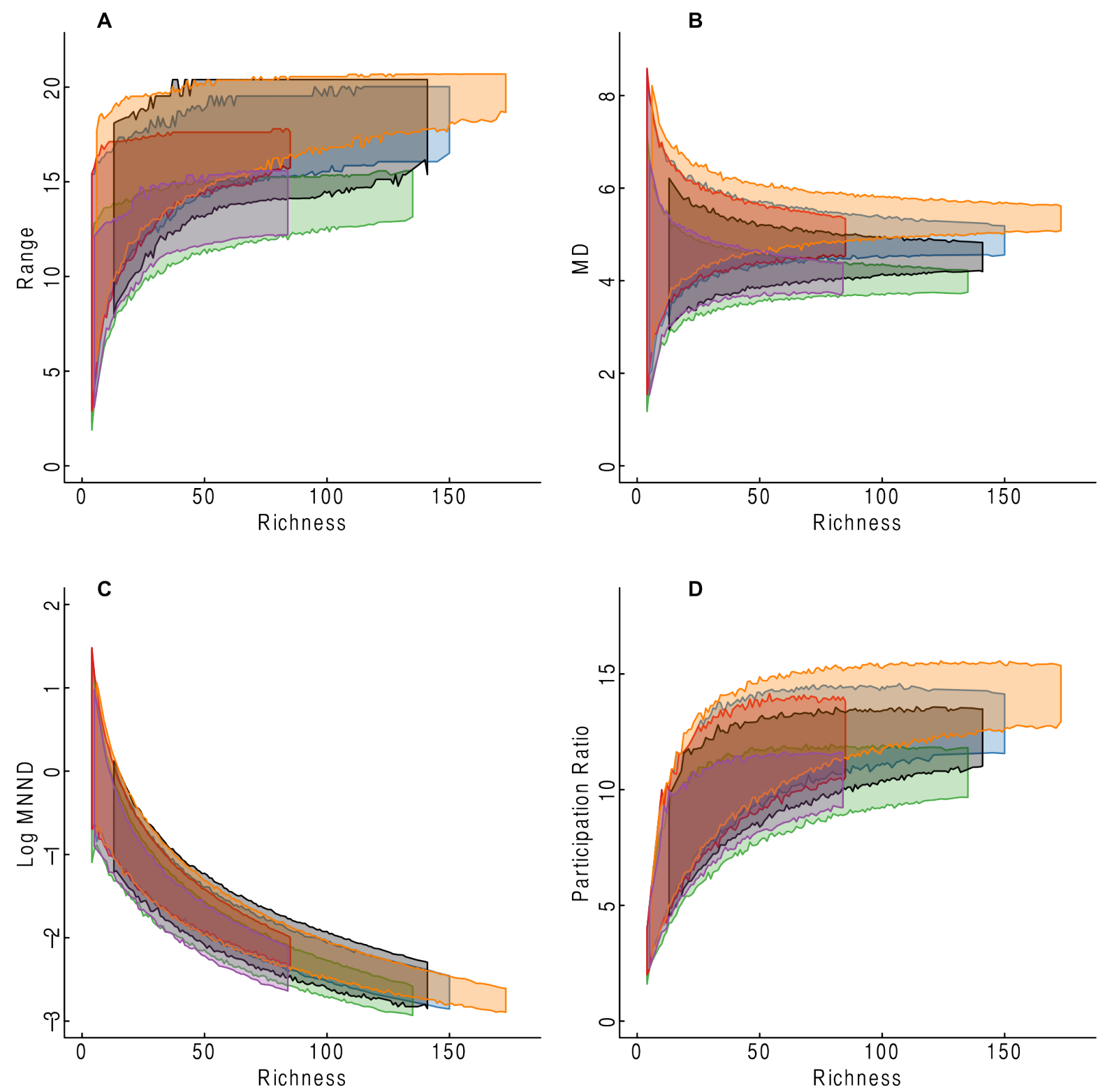

Figure 1.8: Polygons showing the expected relation between disparity measures and species richness for the different Regional pools used here. This panels clarify the comparison between different regional expectations since the same polygons are shown in Figure 1.4. A - Range; B - MD; C - MNND; D - PR.

The remaining continents do not show an overwhelming striking pattern across most of their geographic area, except perhaps the Australian realm. Through most of Australia, body mass Range is uniform (Figure 1.5A) and within the expected by the Global Pool, except for richer coastal areas where the low values observed for Range are smaller than expected (Figure 1.7). MD is higher on Australian grasslands, which is within the 
Global pool confidence interval but is higher than expected by the Regional Pool. On the other hand Australian deserts show values of PR that are smaller than expected by both Global and Regional Pools. The Papua-New Guinea Island is part of the Australasian realm and show disparity values smaller than expected for all metrics when we compare it to the null model using the Global or Regional pool.

The northern portions of Neartic and Paleartic regions show high values for three disparity metrics (Range, MD and PR). However, only MD is higher than expected for significant portions of extreme North latitudes when comparing to the Global pool (Figure 1.7). Neartic temperate grasslands show lower than expected Range and MNND, also when comparing to the Global pool (Figure 1.7). This pattern is different from Paleartic grasslands, which show lower than expected MD and PR (Figure 1.7). All these patterns for Neartic and Paleartic realms are further accentuated when comparisons are made to the Regional pool since more cells deviate from null expectations (Figure 1.7). The comparison with Neartic Regional pool, showed that body mass Range is lower than expected not only in the realms' grasslands but also on most its southern area. Similarly, southern Neartic show MD values lower than expected by the Regional pool, which was not so clear when the Global pool was considered.

The highest values of Range, MD and PR are observed in African Savannas, but only MD and, to a less geographical extent, PR show considerable deviations from the Global null model (Figures $1.3 \& 1.7$ ). These high values of MD and PR suggest that within those cells the morphospace is more evenly occupied than would be expected by a global pool of species, i.e. species are less clumped in the morphospace. When the Afrotropics Regional pool is considered MD and PR deviance from expectation is also observed in the Savannas, but becomes restricted to smaller areas. We observed lower than expected MD in African Tropical Forest, when comparing to the Regional pool. Very large animals are also present in parts of the Indo-Malay realm, and the values of Range reach levels similar to the observed in African Savannas. Except for few areas where large values of Range are above the expected, the overall pattern is that Range values are within the confidence interval for both Global and Regional pools at the Indo-Malay realm. The Tropical forests of East continental areas and of large islands in the Indo-Malay realm show estimates of the MD and PR smaller than what we would expect for the observed species richness when comparing to the Global pool (Figure 1.7). However this pattern is not strong in continental areas when comparing to the Regional Pool. Most of Indian coniferous tropical forests show lower than expected MNND when compared to both Global and Regional pools.

It is interesting to note that the Regional and the Global null models yielded similar patterns except for the Neotropics where the results are considerably different. For the other regions changing the geographical scale of the species pool did not drastically 
change the pattern but rather made some idiosyncrasies of each realm more evident. For example, the comparison of Neartic observed disparity pattern to the expected by the global pool showed a light North-South gradient on the deviation from the null model with cell showing higher than expected disparity at the North and lower than expected disparity at the South. This gradient was easier to observe when the Regional pool was considered, especially for Range and MD, and to a less extent to MNND. On the other hand, the change to the regional pool either masked or accentuated some patterns seen at the global pool on Africa. Extensive Savanna areas where highlighted when compared to the Global pool, a pattern that disappear for the Regional null model. However, Africa's tropical forest seems to be different from the rest of the region, but doesn't show any differences when the Global pool is considered. It is important to note that a large area of the Africa's tropical forest is not different from the rest of the continent.

\subsection{Discussion}

Our results clearly suggest that different biogeographic realms have different levels of morphological disparity when compared to what would be expected for a global relationship between disparity and species richness. The Neotropical realm is the one that mostly deviates from this null expectation suggesting that the role of total morphospace occupation and ecological redundancy might be very different at the continental scale. This difference could arise either because continents have very different historical contingencies (Ricklefs, 1987), because they accommodate differences in species richness in distinct ways (Weiher \& Keddy, 2001) or a combination of both.

\subsubsection{Disparity vs. Diversity}

An increase in species richness could be generated either by expanding total ecological (or morphological) space or by packing more species in the same preexisting niches. In fact, the concomitant increase of morphospace volume and species richness has been previously described as a general pattern for vertebrate communities (reviewed in Ricklefs \& Miles, 1994). On the other hand, the same empirical studies on local vertebrate communities revised by Ricklefs \& Miles (1994) showed no relationship between species richness and MNND suggesting that ecological similarity is absent even in richer communities. Taken together, these results led Ricklefs \& Miles (1994) to suggest that increases in diversity in vertebrate communities are mainly attained by adding species at the borders of the morphospace, and that competition limits the presence of similar species. Although we did not statistically test the association between different disparity metrics 
and species richness, our raw data suggest that an increase in total morphospace (here measured as the body mass Range) might not be the only important mechanism to allow for richer terrestrial mammal assemblages, but that ecological redundancy, specially for some geographical areas such as the Neotropics, might also be important.

Our data suggests that body size Range increases concomitant with species richness, but it quickly levels-off (Figures 1.3). Thus initially modest increases in species richness represent a fast increase in total morphospace. After a certain point the addition of more species does not constitute an increase in the total array of morphological possibilities, but rather the gaps within this range might be filled in as more species are considered. This suggests that the addition of new morphologies at the periphery of the morphospace and internal packing are both relevant when accommodating more species. These results contrast to those reported for vertebrates by Ricklefs \& Miles (1994) and we suspect there are two main reasons behind such difference. First, we should note that our characterization of the morphospace is unidemensional and that Range of body mass is a metric highly influenced by extreme values. Other studies (Shepherd 1998, and references in Ricklefs \& Milles 1994) have considered not only body size but also body shape, which may offer more resolution when characterizing species niche based on morphology. Therefore it is possible that the occupation of total morphospace would continue to increase with species richness in another axis of the niche space that was not evaluated here. Second, there is a difference in scale between our analysis and those of local communities, which might translate into an evaluation of different patterns with very different sample sizes. When compared to traditional community ecology studies, a macroecological approach comprises a larger number of assemblages. Thus, the tendency of total morphospace volume to level-off might not be detected for local community studies simply due to a sample size not large enough to reveal such pattern. In fact, other macro-ecological studies that considered a large number of assemblages also didn't find any clear relationship between total disparity metrics (including total niche space) and species richness (Neige, 2003; Ricklefs, 2012) or found an increases in total morphospace volume with species richness that levels off at higher richness (Roy et al., 2001).

Another important difference between our results and those of previous studies (e.g. Ricklefs \& Miles, 1994) is that we find strong evidence for ecological redundancy at assemblages with more species. This is inferred by simultaneously looking at the Range level-off and the concomitant decrease in MNND and increase in species richness, as well as the tendency of PR to increase and eventually level-off with increasing richness. At intermediate species richness the value of body mass Range has already attained its maximum, thus increases in richness seem to be accomplished by filling the gaps in the body mass, which is demonstrated by the continuous initial increase in PR and decrease 
in MNND. When high levels of diversity are reached then redundancy in body mass starts to arise and it is possible to see that PR levels-off.

An important difference between our analysis and many studies of local communities is that those local studies usually focus on species of the same guild while we included all terrestrial mammals. Here we analyzed grid cells that harbor species from very different guilds. Assuming that different guilds can possibly be inferred from different body masses, it is possible that the initial fast increase in body mass Range represent the addition of new guilds (with completely different body masses) and its concomitant level-off, the decrease of MNND, and level-off of PR might suggest that further increases in richness represent the addition of morphological redundancy of species belonging to guilds already present. This hypothetical scenario suggests that assemblages with intermediate species richness will have most of the functional groups or guilds found on the richer assemblages but that those will be occupied by fewer species. This is similar to the results of Safi et al. (2011) who reported an initial fast increase in functional diversity with increasing richness that later slows down when larger richness is attained. Also, this scenario seems to be in accordance with the relationship between disparity and diversity at a temporal scale, since most paleontological data suggest a scenario where disparity increases first and then diversity catches up (Benton, 2015).

We should also note that once species richness increases it is possible that richer areas might further accumulate species by increasing specialization. In this scenario species with similar size would show a smaller niche breadth that allow them to coexist and perhaps avoid competition (MacArthur \& Levins, 1967). For example, it is known that two grazers, Zebras and gnus, eat different portions of the grass blades: while zebras eat the tips, Gnus tend to eat the middle portion of the leaf (Gwynne \& Bell, 1968). Similarly, on deep time there is evidence that increases in the degree of ecological specialization is associated with increases in diversity in at least three important marine invertebrate groups (brachipods, gastropods and bivalves - Nürnberg \& Aberhan, 2015). Such specialization mechanism could also be acting on extant mammals assemblages but our analysis is not able to tell this apart from the scenario of increase ecological redundancy advocated here. In both we would expect to see a decrease in MNND and an increase in PR. More importantly, although we discuss the potential relationship between disparity and richness and this helps to understand our main question (the continental effect on disparity and richness) a proper description of such relationship requires the use of spatial explicit models (Legendre, 1993) and should be done in the future. 


\subsubsection{The effect of Biogeographic realms}

The most striking result we found in our analysis is the consistent difference of the Neotropics to other biogeographic realms. The Neotropics strongly departs from the global null model on the following disparity metrics: body mass Range, Mean pairwise Distance, and Participation Ratio. This departure occurs not only in few cells with a certain number of species, but virtually in all of its geographical extension and all levels of species richness (Figure 1.7). This suggests that the Neotropics either accumulated species in a very different way, that historical factors are relevant, or that it has suffered a loss in diversity that is in nature completely different to what might have happened on other biogeographic realms.

It is well known that an extinction event during the late Pleistocene, possibly related to human geographic expansion, preferentially stroke the megafauna (Koch \& Barnosky, 2006) and that such extinction event was not equal across different continents (Lyons et al., 2004; Smith \& Lyons, 2011). Therefore it is an open question on how these extinctions might have changed the relationship between disparity and richness we see here. If the Neotropic region was affected in a unique and different way, such extinction event could generate a bias in some of our estimates, most notably on Range, and render some of those deviations from the null model as a direct by-product of the megafauna extinction. Contrary to this assertion, we see that those departures are not solely produced by the lack of very large animals, given that removing species larger than $100 \mathrm{Kg}$ and reanalyzing the data resulted in virtually identical patterns for both the Neotropics and other biogeographic realms (Figure 1.7). We suspect that South America history of isolation (Wilf et al., 2013) might have played an important role on the recovered pattern and this continent might have a different "set of rules" on how to add more species with respect to the occupation of the morphospace.

On all biogeographic realms the smallest terrestrial mammal species either belong to Soricomorpha or to Afroscoricidae and weight between 2 and 4 grams. Soricomorphs are the smallest mammals in the Neotropics, but those very small Soricomorph species only occur in Central America. In South America (southern than Panama) the smallest specie is an opossum with restricted geographic distribution (Gracilinanus emiliae $7.6 \mathrm{~g})$. Therefore we suggest that the lack of species in the smallest category in South America is responsible for the shorter Range in body size irrespective of the absence created by the megafauna extinction. It is interesting to note that Australia's Range in body mass is also constrained on both sides; very small and large species are also absent. The first is likely related to the fact that Soricomorpha and Afrosoricida never reached the Australian realm, and the later because the megafauna also became extinct during the late Pleistocene (Koch \& Barnosky, 2006). However Australian body mass Range, 
differently from South American Range, is within the expected for its relatively low species richness (usually lower than 50 species - Figure 1.1). The Neotropics also shows lower than expected MD and PR (Figure 1.7), but we suspect that the lack of very small and very large species per se might not be enough to explain these observed deviances. It is also important to note that a decrease in Range is not necessarily associated with a decrease in MD. Therefore the lower than expected MD observed in the Neotropics can be viewed as an evidence for the clumping of species in the morphospace, at least when compared to the null expectation. This is corroborated by lower than expected $\mathrm{PR}$ values for South America, since low PR values mean that the morphospace is not evenly occupied. We believe that the explanation for why Neotropical species seem to be clumped in the morphospace is related to a high number of intermediate size species (between $200 \mathrm{~g}$ and $1 \mathrm{~kg}-7.5$ and $10 \mathrm{in} \log 2$ scale), which is unusual in other regions (Marquet \& Cofre, 1999, and see Chapter 2). The observation of the first quartile of body mass reinforces this idea, in South America this quantile is around 360 grams, whereas in most of the other regions (except for a great portion of the Indo-Malay realm) the first quartile is about $45 \mathrm{~g}$ (Figure 1.6). A further examination of the data shows that most of these intermediate species belong to groups that have evolved in South America such as marsupials, xernarthrans, Platyrrihini monkeys, and caviomorph rodents. Therefore, taking together the results from Range, MD and PR we suggest that South America shows evidence of niche packing, specifically at intermediate body masses. This is conceptually similar to Safi et al. (2011) who also found evidence of niche packing in the Neotropics when looking at mammalian functional diversity and its relation to phylogenetic diversity, but we provide an explicit hypothesis on where in the morphospace the packing has happenned.

It is interesting to note that most intermediate size species are arboreal, and given extensive forest coverage in the Neotropics (Olson et al., 2001) it is possible that such packing is related to locomotion habit. If this pattern is indeed determined by environmental conditions then we should expect some similarities with other regions with extensive forest cover. In fact tropical forest areas of large islands and east continental Indo-Malay region show levels of MD similar to those in the Neotropics, while PR is also low (even though it is within the expected for the null models - Figure 1.5 and 1.7). This pattern is observed even with large species present in the Indo-Malay region, suggesting that tropical forests could in fact be responsible for the observed niche packing, at least revealed by body size. However higher levels of MD and PR (which suggest an even occupation of the morphospace) are seen in most of Africa's equatorial forest, thus we do not find a general rule for the relation of niche packing and environmental conditions. Rather, there seems to be a complex scenario, where niche packing might depend on the taxonomic groups present within a region and the environment where 
they evolved. Therefore, local assemblages might be strongly influenced by regional processes (Ricklefs, 1987) and in the case of South America we suspect its history of isolation between 50Mya and the closure of Panamanian Isthmus (Wilf et al., 2013) have strongly influenced the regional and therefore local dynamics of species diversity.

There could be different ways through which the effect of history could have led to the pattern of body mass packing we observed in the Neotropics. As far as we are aware there are no evidences of mammals as small as soricomorphs that have evolved in the Neotropics. Therefore, South American endemic mammal fauna appears to have never occupied the lower end of body size distribution typically seen in other parts of the globe, but rather to have created a higher abundance of intermediate size species. This limitation could be a consequence of morphological constrains associated with South American groups that prevented those lineages to evolve niches associated with very small body size. Therefore the initial composition of neotropical mammals might have have strongly influenced the observed outcome of morphological disparity. On the other hand South America has clearly exchanged species with North America (Woodburne, 2010) and such exchange could have allowed very small mammals into South America. In fact many of the small mammals occurring in South America are sigmodontine rodents (Marquet \& Cofre, 1999), a lineage that have first evolved in North America, although those never reach the very small size seen in soricomorphs in other parts of the globe. As mentioned above, soricomorphs, have successfully colonized Central America, but not South America, not even in the last 3.5 million years which corresponds to what seems to be the widely accepted time for the closure of the Panamanian Isthmus (Wilf et al., 2013). Moreover, (Bacon et al., 2015) argued that American biota exchange started long before 3.5 million years which suggests no shortage of time for such migration to happen. However we should note that to achieve some parts of South America animals should have had to transpose high passes on the Andes, which may be more difficult in the tropics given the broader climatic tolerances required to cross a moutain (Brown, 2014). Thus a dispersal limitation could have still restricted the geographic expansion of the group, especially knowing that better dispersal abilities are associated with larger body masses (Morales-Castilla et al., 2012). Alternatively, it is possible that the absence of small species in South America could be the consequence of competition. Under this scenario an incumbent clade (Rosenzweig \& McCord, 1991) could have prevented successful colonization of lineages with small body size or even the evolution of small body size in situ. If the incumbent effect is relevant, it would suggest that a clade other than mammals, and therefore not analyzed here, would be occupying the niche associated with very small body size. This hypothesis can account for the fact that soricomorphs of very small body size are present in Central America, but not South America. However invertebrates in general compose the diet of soricomorphs, thus it 
is difficult to imagine a shortage of dietary resources, and, the incumbent hypothesis would request competition for a resource different from diet. Lastly, it is also possible that the lack of very small species in South America might be due to a to a top-down control, i.e. the presence of predator (Paine, 1966) or parasites (Ricklefs, 2010) that hinders the successful colonization or evolution of mammals lineages with small body size impossible.

We should note that when examining body size distribution for whole continents and using a very different approach (Chapter 2) we also find evidence for a unique pattern of South America. It is also worth noting that South America is the only continent where a change in the species pool (Global vs. Regional) drastically affects the results against the null model. This reinforces the idea that factors acting at a regional scale and not at a local scale determine the unique disparity values we see in South America. Thus we suspect that historical factors, in conjunction with ecological setting, might have played an important role on producing a more packed niche space and therefore a different way to accommodate morphological disparity and species richness in this region.

We emphasize that caution should be taken since our argument on the existence of niche packing is based solely on body mass as a surrogate of niche and species might differ in other traits that were not accounted here. In fact the main motivation to discard bats was because they show considerable overlap in body mass with small mammals but have a very different ecology. Also there are cases where it is known that species differentiate in other axis that can be used to describe niche. For example, (Shepherd, 1998) reported high cranial shape diversity coupled with low body mass diversity in a Central American community. Other potential smaller limitations on the use of body size might be worth mentioning. For example, sexual dimorphism could lead to differences in niches, such that intra-specific competition for resources could be diminished (Bolnick \& Doebeli, 2003). Also species body mass could vary with environmental conditions, e.g. Bergman's rule, where larger individuals are present in colder parts of a species geographical distribution (Blackburn et al., 1999). Although those clearly affect our ability to precisely estimate body size for some species at different geographical areas, given our broad taxonomic scale we suspect the differences produced by variations between sexes or between populations are small when compared to the variation among all terrestrial mammals used. Analysis carried with "big data" certainly carry some imprecision on estimates of traits of interest, but the large scale perspective should ensure that no systematic biases would be introduced given that differences among the parameters of interest are usually higher than the small difference that result from such imprecisions. Therefore we suspect that including more detailed body mass data would not change the observed pattern of niche packing in South America. Ecologists have commonly used body mass as surrogate of ecology since it correlates with most life history traits 
(Bonner, 2011), we assume that if used with caution as done here, body size should in fact be a good proxy for ecology. We suggest that the patterns seen here represent evidence for niche packing at South American terrestrial mammals assemblages rather than a particular property of body mass. 


\section{Chapter 2}

\section{Effect of Quaternary extinctions on Mam- malian body mass distribution on dif- ferent continents}

This chapter is presented in the form of a manuscript, which is currently in preparation to be submitted for publication. Authors: Daniel V. de Latorre, Mathias M. Pires and Tiago B. Quental.

\subsection{Introduction}

Body size reflects a series of ecological properties and it is the most studied trait of living organisms. It can be measured in different ways and the most common ones are linear distances (e.g. length) and body mass. Body mass seems the most appropriate measure if one is interested in comparing organisms that span a wide range of taxa, given that comparable linear measurements may not be readily detectable for distinct forms (Gaston \& Blackburn, 2000). More interestingly, body mass correlates with several ecological and physiological properties such as abundance, strength, speed, metabolism and longevity (Bonner, 2011). Therefore it can be viewed as a crude proxy for organism's ecology or physiology and as a heuristic trait to investigate how different aspects of an organism and its environment might be linked. For example, larger organisms have slower metabolism than smaller ones, a restriction presumably imposed by constrains in resource availability or over-heating (Bonner, 2011). These differences in metabolism may underlie the processes that lead to longer longevities observed in larger organisms (Bonner, 2011). Above the individual level, body mass also affects ecological aspects of biological organizations. For example, larger species usually show lower population abundances (White et al., 2007). The ecological meaning and the easiness to collect body mass data have in fact made the study of body mass and its implications a very active research agenda (Smith \& Lyons, 2013).

There is plenty of evidence that small-species greatly outnumber than large-bodied ones. The accumulation of small species results in a distribution of body mass skewed to the right, even on logarithmic scale, both for global and continental assemblages (Maurer 
et al., 1992; Kozłowski et al., 2002). This pattern is observed in most taxonomic groups, but is particularly evident for terrestrial organisms (Gaston \& Blackburn, 2000), and has been mainly studied for terrestrial mammals (e.g. Brown et al., 1993; Marquet \& Cofre, 1999; Smith et al., 2004). Several mechanisms have been proposed to explain the observed patterns of body mass distributions (Allen et al., 2006), several of which consider a mode for small species and a continuous decay in species number towards large size species (Hutchinson \& MacArthur, 1959; Blackburn \& Gaston, 1994). The modal body mass has been interpreted as the size in which most resource consumption can be converted to reproduction, thus it is considered the size that optimizes fitness (Brown et al., 1993).

However studying body mass distribution for extant species only might bias our perception and hinder our interpretations to a limited set of mechanisms, given that historical factors affected body size distributions (Lyons et al., 2004). For example, in North America, the vastly studied mammalian fossil record suggests that body mass distribution became bimodal around 40Mya (Alroy, 1998, 2003; Lyons \& Smith, 2013) and so remained until late Pleistocene when the size-biased extinctions of megafauna eliminated the mode comprising large species (Smith \& Lyons, 2011; Lyons \& Smith, 2013). In fact, studies of extant North American mammals suggest that their current body mass distribution fits an unimodal distribution (Brown et al., 1993). Given that South America and Australia, were also particularly affected by the Pleistocene megafauna (species larger than $44 \mathrm{Kg}$ ) extinction event (Koch \& Barnosky, 2006) it is possible that a bimodal body mass distribution was present in all major continents prior to megafauna extinctions (Smith \& Lyons, 2011; Lyons \& Smith, 2013). Interestingly, in Africa, where the megafauna survived to the Holocene, the current body mass distribution in fact fits a bimodal distribution (Lovegrove \& Haines, 2004; Kelt \& Meyer, 2009). Eurasia seems to be an intermediate case, because significant extinction of megafauna occurred in Europe, but a few megaherbivores such as the Asian elephant and three rhino species still inhabit Asia (Koch \& Barnosky, 2006).

Because body mass is a proxy for other biological traits and ecology, changes in body size distribution might also reflect changes in the ecological properties of local and regional assemblages. Thus fitting different statistical distributions to body mass empirical data is more than a purely statistical exercise, as it might reveal and how natural assemblages might change when faced with a changing environment. For example, understanding how body mass distribution changes over time might be especially relevant if we consider that humans are the main driver of changes in the world's biota comparable to what was produced by the "big five" mass extinctions (Barnosky et al., 2011) and that we can access body mass information for a large number of species. In fact, for most groups, and certainly for mammals, large species face higher extinction risk so 
it has been suggested that the current biodiversity crisis might be size selective, similar to the late Quaternary extinction (Cardillo et al., 2005; Dirzo et al., 2014). Given the importance of large species in food webs and in shaping the environment, the effects of large-bodied species loss are expected to cascade, thus affecting ecological communities' composition and ecosystem services (Dirzo et al., 2014). As the Anthropocene unfolds, an unanswered question is if the changes in mammalian assemblages will be comparable to those experienced in the late Pleistocene. To address this question we quantified the effect of Pleistocene and Anthropocene extinctions on the mammalian body mass distribution across the globe. We compared body mass distribution of the Holocene to body mass distributions prior to the Pleistocene extinctions and to a drastic scenario of the Anthropocene where all threatened mammal species are lost. Specifically, we contrast the goodness of fit of different models, which were previously suggested to describe body mass distributions, and examine how the shape of these body mass distributions have changed in each continent since the Pleistocene. On doing so, we statistically test Lyons \& Smith (2013) verbally proposed hypotheses that the second mode of mammals body mass distribution was eliminated due to late Pleistocene extinctions and we provide a picture of future possibilities for the Anthropocene.

\subsection{Materials and Methods}

To describe the effect of Quartenary extinctions on body mass distributions, we used species mean body mass (in $\log _{10}$ scale) and continental occurrence of terrestrial mammals (volant and marine were excluded) as provided in the Macroecological Database of Mammalian Body Mass (MOM 4.1 - Smith et al., 2003). In MOM species are classified in one of three categories: i) "Extinct": species that went extinct in late Pleistocene, which includes the extinct megafauna; ii) "Historical": species that went extinct in historical time; and, iii) "Extant": species alive today. We used IUCN RedList status to define threatened species as those listed within the status Vulnerable, Endangered, Critically Endangered, Extinct in the Wild and Extinct. This allowed us to analyze body mass distributions of three time frames: 1) Pleistocene: including all species assigned to the "Extant", "Historical" and "Extinct" categories; 2) Holocene: all species except those in the "Extinct" category; and 3) Anthropocene: excludes all "Extinct" species, species assigned to the "Historical" category and extant species considered threatened following the IUCN categories described above.

We analyzed the body mass distribution in each time slice for all mammals combined (global) and also for the assemblages of five major continents (see Figure 2.1): North America (including Central America), South America, Eurasia, Africa and Australia. 

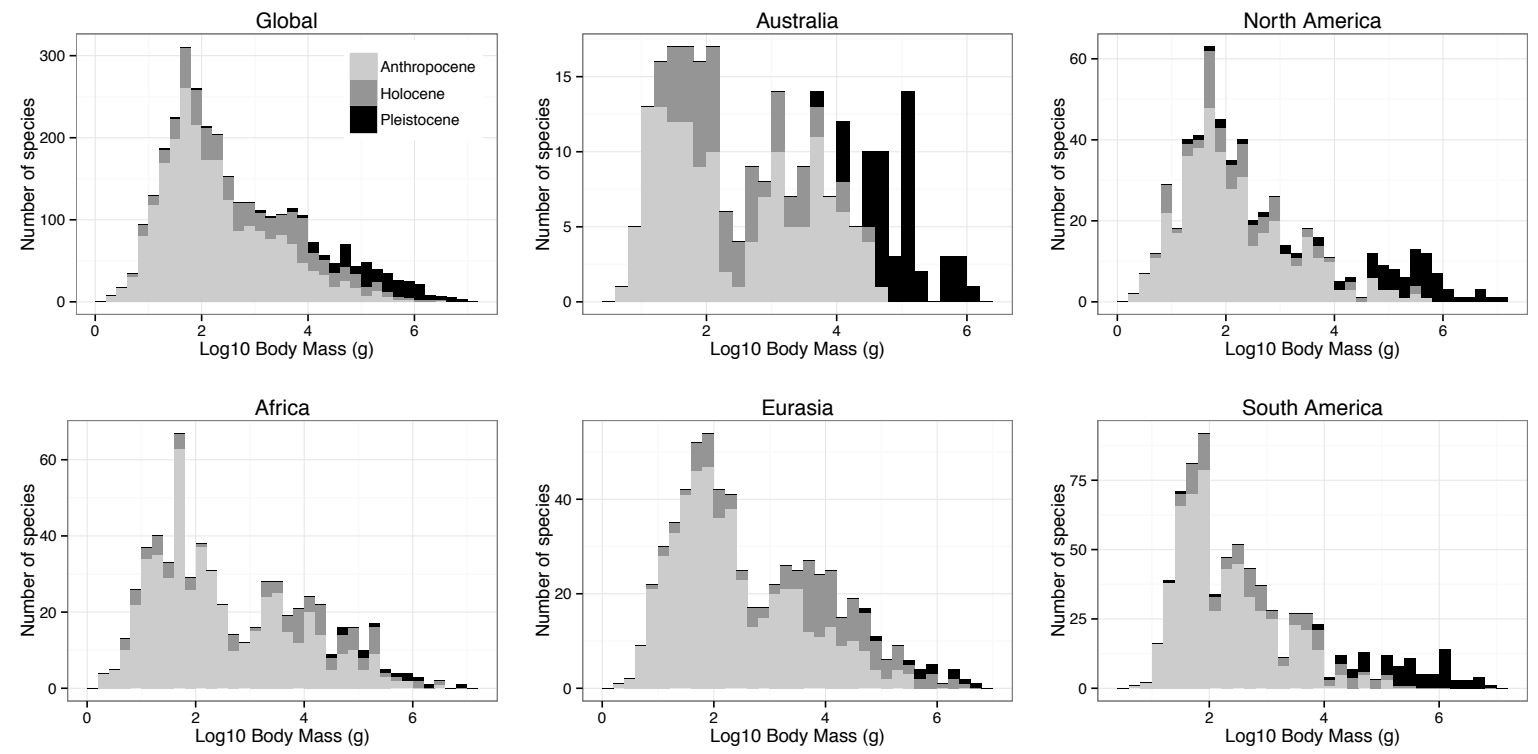

Figure 2.1: Histograms showing body mass distribution (in grams - $\log _{10}$ scale) of terrestrial mammals for all species combined (Global) and for species of each continent separately. Colors represent the three time slices considered: Black - species extinct in the late Pleistocene; Gray - extant species in the Holocene that are either threatened or extinct in historical time; Lightgray - extant and not threatened species.

We used the species occurrence data provided in the MOM dataset to define the occurrences in each continent. The number of species considered in each continent by time slice is presented in Table 2.1. Some species show different body mass in each continent, in these cases we calculated the mean body mass value of different continents to perform the global analysis.

Table 2.1: Species counts per continent for each time slice considered (refer to main text for time slice definitions).

\begin{tabular}{cccc}
\hline & Pleistocene & Holocene & Anthropocene \\
\hline Africa & 617 & 604 & 511 \\
Australia & 243 & 198 & 143 \\
Eurasia & 638 & 627 & 491 \\
North America & 560 & 484 & 408 \\
South America & 736 & 658 & 554 \\
\hline Global & 3136 & 2900 & 2283 \\
\hline
\end{tabular}

We compared the fit of two models often cited in the literature to account for mammalian body mass distribution, the unimodal and the bimodal distribution. To account 
for skewness in the unimodal scenario, we fitted a Skew Normal distribution, which is described by three parameters: Location $(\xi)$, Scale $\left(\omega^{2}\right)$ and Skew $(\alpha)$. When the Skew parameter equals zero, we obtain the standard Normal distribution. The second model, the bimodal distribution, is described by a mixture distribution of two standard Normal distributions. This model has five parameters, a location (mean, $\mu$ ) and scale (variance, $\sigma^{2}$ ) parameter of each Normal distribution and a mixture parameter (a) that determines the contribution of each Normal to the final distribution. In this case if the smaller distribution contributes with $a \%$, than the contribution of the second distribution is $(1-a) \%$. We used the Akaike Information Criterion (AIC) to compare fitted models and to determine which one better described the mammal body mass distribution. We repeated this analysis for all species combined (global) and for each continental assemblage separately for the three time slices (Pleistocene, Holocene, and Antropocene) considered. AIC differences greater than 2 were used as a criterion to chose one model over the other. All analyses were realized in $\mathrm{R}$ and we used packages bbmle (Bolker, 2008) and sn (Azzalini, 2015) to perform the model fitting.

\subsection{Results}

Our analysis showed that the global body mass distribution of mammals is in fact bimodal for the three time slices analyzed (Figure 2.2 left column, Table 2.2). However, the best estimated parameters of the model changed over time. The first Normal distribution describe the mode of higher species density with a mean around $50 \mathrm{~g}$ (1.7 in $\log _{10}$ scale - Table 2.3) that barely varied through time. On the other hand, the second Normal distribution significantly changed over time. By the late Pleistocene, the second peak showed a mean around $3.8 \mathrm{Kg}$ (3.59 in $\log _{10}$ scale). This value dropped to $1.9 \mathrm{Kg}$ in the Holocene (3.28 in $\log _{10}$ scale), demonstrating how the loss of the megafauna in several continents affected the global body mass distribution. In case of a severe extinction during the Anthropocene the mean of the second Normal distribution drops even further to $1.29 \mathrm{Kg}$ (3.11 in $\log _{10}$ scale). These parameter variations show that the two modes are becoming more similar since the Pleistocene and that extinction clearly affected the second Normal distribution preferentially. Although, at a global scale the contribution of the second Normal distribution is progressively smaller as we approach the present and predict future extinctions, the bimodal model is still favored when compared to the Skew Normal distribution, even in the Anthropocene scenario. The parameter $a$ representing the relative contribution of the first Normal (smaller mode) to the bimodal pattern, shows that by the end of the Pleistocene the second Normal contributes with $48 \%$ to the global pattern, and this value decrease to $47 \%$ on the Holocene to finally 
Body Mass Distribution
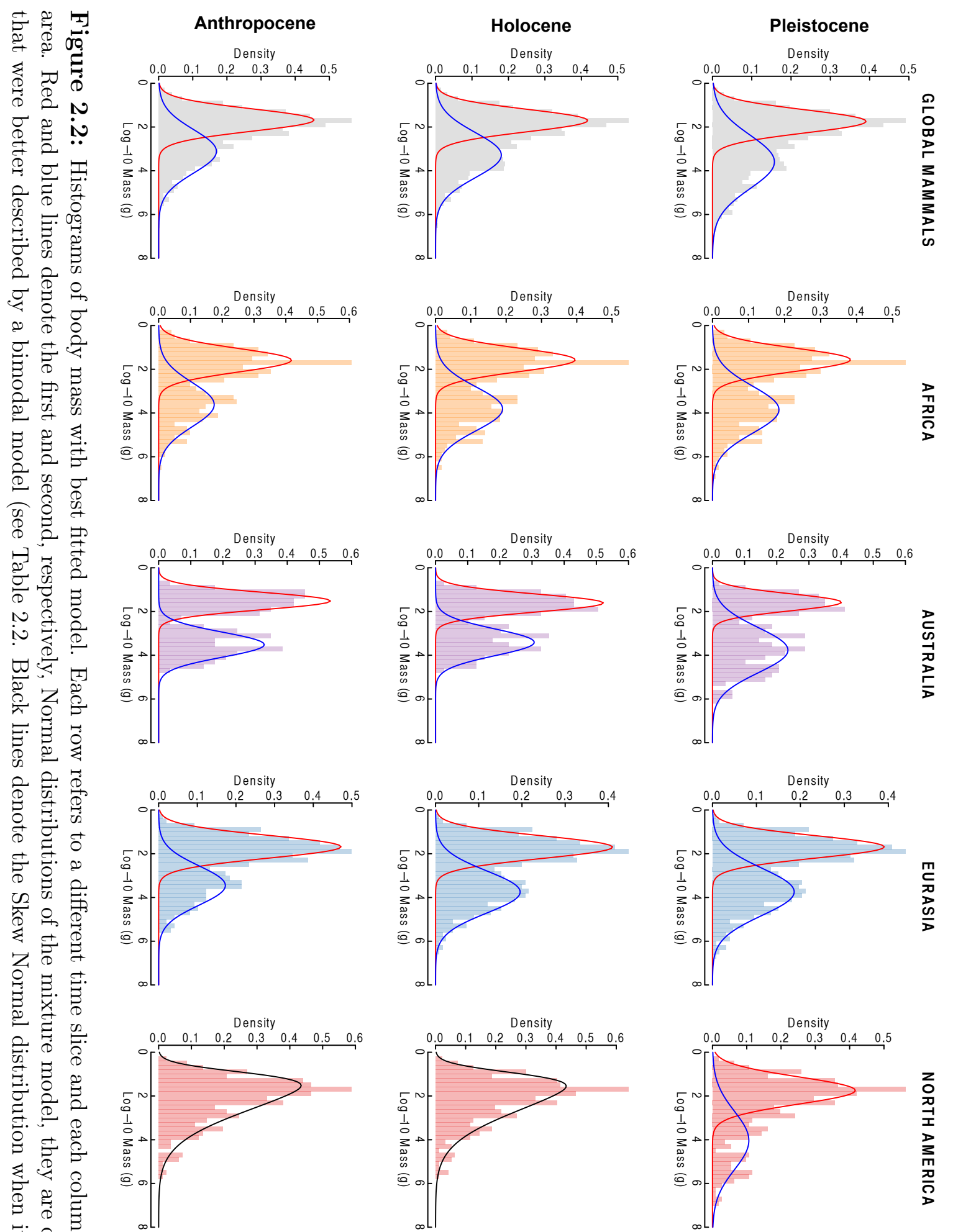

얄

要量

है 0 ०

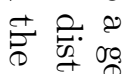

क

古
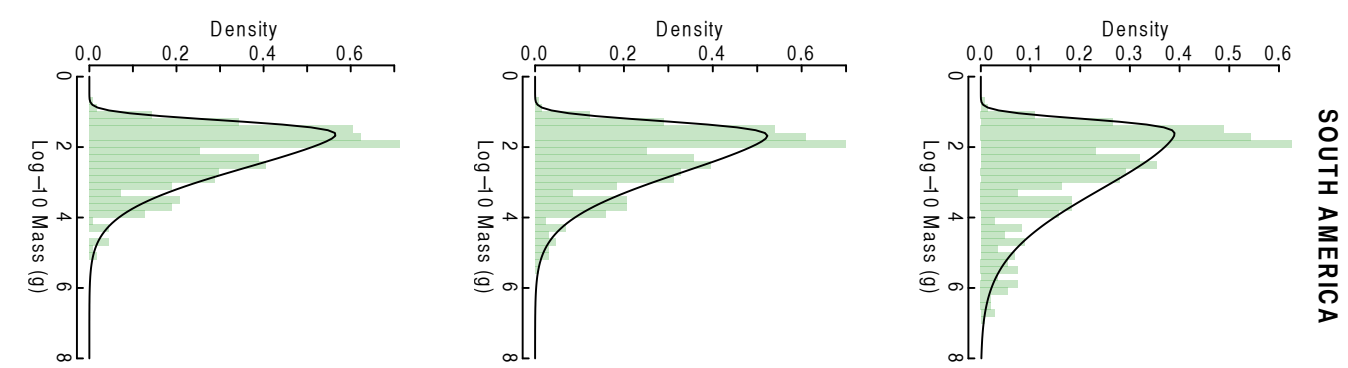
achieve $42 \%$ in the Anthropocene (Table 2.3).

Table 2.2: The two models Skew Normal (SN) and Bimodal (Bimod) where compared through AIC difference $(\triangle \mathrm{AIC})$, this way zero indicate the best model. Differences higher than two where considered significant. Numbers in parentesis are the weight attributed to each model.

\begin{tabular}{rcc|cc|cc}
\hline & \multicolumn{2}{c|}{ Pleistocene } & \multicolumn{2}{c|}{ Holocene } & \multicolumn{2}{c}{ Anthropocene } \\
& SN & Bimod & SN & Bimod & SN & Bimod \\
\hline Global & $69.60(<0.001)$ & $0.00(1.00)$ & $55.06(<0.001)$ & $0.00(1.00)$ & $30.68(<0.001)$ & $0.00(1.00)$ \\
Africa & $47.01(<0.001)$ & $0.00(1.00)$ & $47.93(<0.001)$ & $0.00(1.00)$ & $24.67(<0.001)$ & $0.00(1.00)$ \\
Australia & $23.75(<0.001)$ & $0.00(1.00)$ & $26.30(<0.001)$ & $0.00(1.00)$ & $29.19(<0.001)$ & $0.00(1.00)$ \\
Eurasia & $31.10(<0.001)$ & $0.00(1.00)$ & $38.29(<0.001)$ & $0.00(1.00)$ & $12.86(0.001)$ & $0.00(0.998)$ \\
North Am. & $23.11(<0.001)$ & $0.00(1.00)$ & $0.00(0.76)$ & $2.26(0.24)$ & $0.00(0.61)$ & $0.92(0.39)$ \\
South Am. & $0.00(0.996)$ & $11.23(0.003)$ & $0.00(0.99)$ & $8.50(0.01)$ & $0.00(0.82)$ & $2.99(0.18)$ \\
\hline
\end{tabular}

The body mass distribution of terrestrial mammals in Africa, Australia and Eurasia was also better described by a bimodal distribution for the three time slices (Table 2.2, Figure 2.2). Contrary to the global pattern, Eurasia and Africa did not show meaningful changes in the second mode after the Pleistocene extinctions (Figure 2.3, Table 2.3). This is somehow expected given that a smaller number of large species disappeared in these continents during the Pleistocene (Koch \& Barnosky, 2006). However, the Anthropocene scenario suggests we might see a considerable loss of large species, which would result in a drastic reduction of mean, variance and contribution of the second mode for those continents (Figure 2.3). For instance, when compared to the variation estimated between the Pleistocene and the Holocene, the changes in the second distribution mean $\left(\mu_{2}^{2}\right)$ from the Holocene to the Anthropocene projection is 30 times larger for Eurasia and 4.75 for Africa, whereas for the global body mass distribution the effect on the mean was 1.82 times larger from the Pleistocene to the Holocene (Table 2.3).

Although Australia was the continent that suffered most losses during the Pleistocene megafauna extinction (Koch \& Barnosky, 2006) it kept its bimodal pattern throughout the Holocene (Figures $2.2 \&$ 2.3; Table 2.2). However, the late Pleistocene extinction led to a decrease of mean, variance and relative contribution of the distribution comprised by larger-bodied species. Bimodality in Australia is still present in the Holocene due to the very low density of intermediate sized species, with mass around 300g. Noteworthy the main difference in the body mass distribution of Australian mammals from the Holocene to the Anthropocene projection is a small reduction in the first distribution mean and an increase in the second distribution mean (Table 2.3), as a consequence of a larger proportion of small and intermediate-sized threatened species (Figure 2.3).

South America didn't show a bimodal pattern prior to megafauna extinction. In fact the Skew Normal model showed better goodness of fit and is more appropriate to describe body mass distribution for the three time slices analyzed. Nonetheless, Pleistocene extinctions significantly changed both parameters $\alpha$ (skewness) and $\omega^{2}$ (scale), while 
Table 2.3: Parameters estimatives for the best model fitted to each continent at three time slices: P - late Pleistocene; H - Holocene; A - Anthropocene. Table A shows parameters of the mixture model: $\mu_{1}$ and $\sigma_{1}^{2}$ describe the first Normal distribution while $a$ is its relative contribution; $\mu_{2}$ and $\sigma_{2}^{2}$ describe the second Normal distribution, which show $1-a$ contribution to the overall pattern. Table B shows estimatives for the Skew Normal distribution parameters Location, Scale and Skew

\begin{tabular}{|c|c|c|c|c|c|c|c|}
\hline & & $\mu_{1}$ & $\sigma_{1}^{2}$ & $a$ & $\mu_{2}$ & $\sigma_{2}^{2}$ & $1-a$ \\
\hline \multirow{3}{*}{ Global } & $\mathrm{P}$ & 1.74 & 0.53 & 0.52 & 3.59 & 1.22 & 0.48 \\
\hline & $\mathrm{H}$ & 1.70 & 0.51 & 0.53 & 3.28 & 1.03 & 0.47 \\
\hline & $\mathrm{A}$ & 1.68 & 0.51 & 0.58 & 3.11 & 0.99 & 0.42 \\
\hline \multirow{3}{*}{ Africa } & $\mathrm{P}$ & 1.57 & 0.53 & 0.50 & 3.85 & 1.07 & 0.50 \\
\hline & $\mathrm{H}$ & 1.57 & 0.53 & 0.52 & 3.81 & 1.00 & 0.48 \\
\hline & $\mathrm{A}$ & 1.59 & 0.53 & 0.56 & 3.62 & 1.01 & 0.44 \\
\hline \multirow{3}{*}{ Australia } & $\mathrm{P}$ & 1.58 & 0.39 & 0.39 & 3.77 & 1.03 & 0.61 \\
\hline & $\mathrm{H}$ & 1.61 & 0.41 & 0.53 & 3.41 & 0.61 & 0.47 \\
\hline & A & 1.52 & 0.40 & 0.53 & 3.52 & 0.57 & 0.47 \\
\hline \multirow{3}{*}{ Eurasia } & $\mathrm{P}$ & 1.69 & 0.51 & 0.50 & 3.74 & 1.08 & 0.50 \\
\hline & $\mathrm{H}$ & 1.70 & 0.51 & 0.53 & 3.75 & 0.96 & 0.47 \\
\hline & $\mathrm{A}$ & 1.68 & 0.52 & 0.61 & 3.45 & 0.90 & 0.39 \\
\hline \multirow{3}{*}{ North America } & $\mathrm{P}$ & 1.75 & 0.62 & 0.65 & 4.03 & 1.33 & 0.35 \\
\hline & $\mathrm{H}$ & 1.63 & 0.55 & 0.61 & 3.06 & 1.04 & 0.39 \\
\hline & A & 1.59 & 0.53 & 0.60 & 3.02 & 1.03 & 0.40 \\
\hline \multicolumn{8}{|l|}{ B } \\
\hline & & \multicolumn{2}{|c|}{ Location } & Scale & Skew & & \\
\hline \multirow{3}{*}{ North America } & $\mathrm{P}$ & 0 & & 2.26 & 7.72 & & \\
\hline & $\mathrm{H}$ & 0. & & 1.64 & 4.63 & & \\
\hline & A & 0. & & 1.64 & 4.72 & & \\
\hline \multirow{3}{*}{ South America } & $\mathrm{P}$ & 1. & & 1.98 & 11.43 & & \\
\hline & $\mathrm{H}$ & 1. & & 1.43 & 7.25 & & \\
\hline & $\mathrm{A}$ & 1. & & 1.32 & 6.80 & & \\
\hline
\end{tabular}


it did not strongly affect the $\xi$ (location) parameter. These changes represent the loss of the distribution's tail, reflecting the biased extinction of large animals. The same tendency, although with a smaller magnitude, was observed when we compared the parameter estimates of the Holocene with those of the Anthropocene (Table 2.3 B), which suggest that the Anthropocene losses will not be as large as those in the late Pleistocene for South America.

The effect of megafauna extinction in North America was strong enough to completely remove the second mode of body mass distribution. A bimodal model showed the best fit to late Pleistocene mass distribution, but the Skew Normal had better fit to the Holocene data (Table 2.2). Although the Anthropocene also show higher likelihood for the Skew Normal distribution, the bimodal model could not be discarded based on the criteria of 2 units of AIC differences (Table 2.2). However the possible second distribution observed for the Anthropocene would be completely different in mean (from 4.03 in the Pleistocene to 3.06 in the Anthropocene) and variance $\left(\sigma_{2}^{2} \mathrm{P}=1.33 ; \sigma_{2}^{2} \mathrm{~A}=1.03\right)$ from the one observed in late Pleistocene (Table 2.3).

\subsection{Discussion}

\subsubsection{Fitting different distributions on current body mass dis- tribution}

The body mass distribution of extant global terrestrial mammals is better described by a bimodal distribution than by a skewed unimodal distribution (Figure 2.2; Table 2.2). In general a bimodal pattern is favored if there are classes of body mass with low species frequency (a "valley"), but this is not especially evident when one observes the body mass distribution of global terrestrial mammals. A prominent gap in the distribution becomes clear only when the distribution of some continents is analyzed separately. Thus, the global pattern may be hiding idiosyncrasies that are specific of each large landmass, which might reflect the influence of regional processes on the structure of biotas (Ricklefs, 1987; Vellend, 2010). Indeed, our analysis suggests that very different body mass distribution patterns characterize each continent. In agreement with the global model, Eurasia, Africa and Australia showed a bimodal distribution of body mass for extant species (Figure 2.2; Table 2.2), but we see relevant quantitative differences between these continents when considering the changes that body mass distributions underwent over time. Considering only extant species, the body mass distribution of the remaining two continents, North and South America, are better described by a skewed unimodal distribution, although support for such pattern is a lot stronger for 

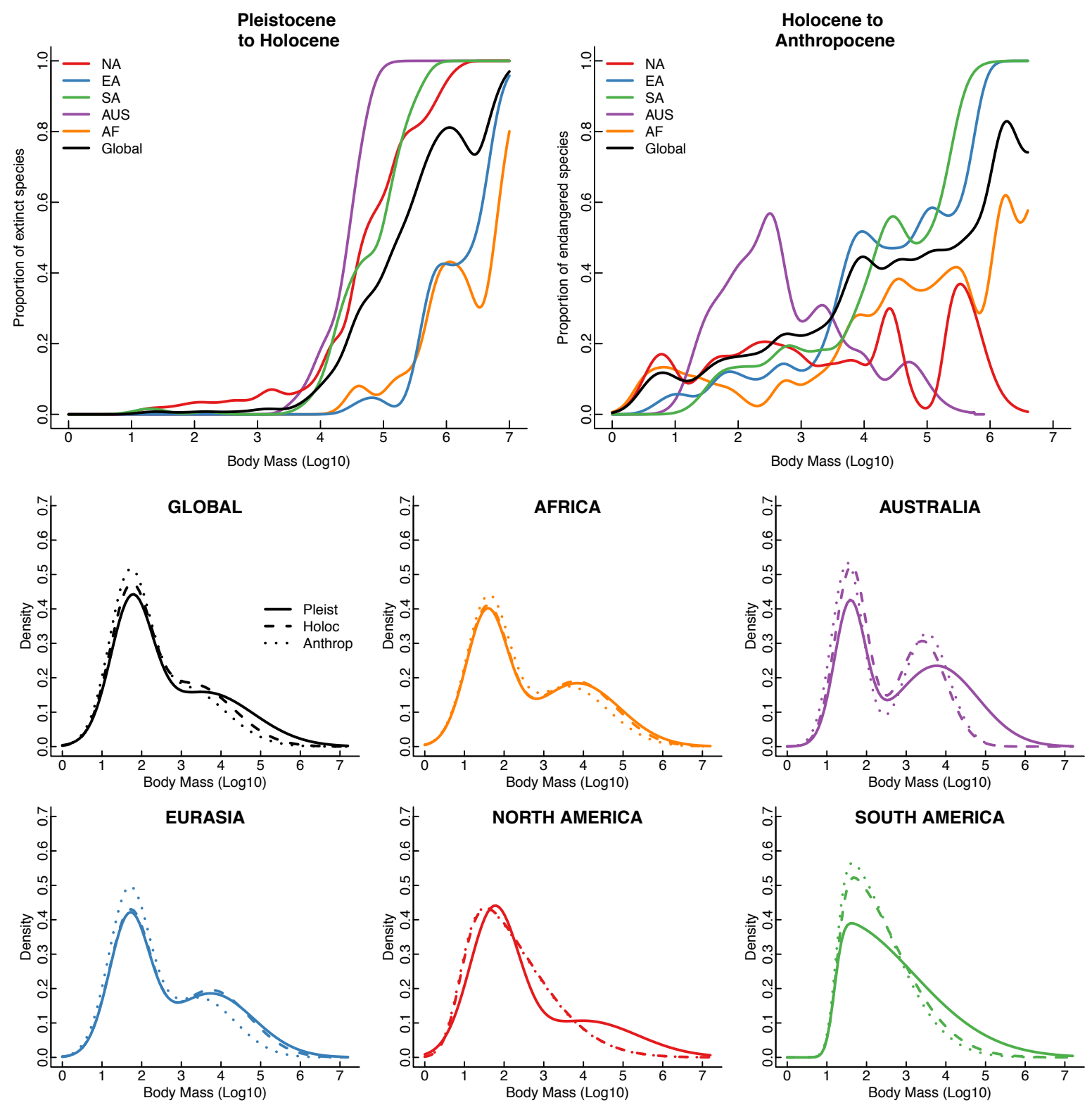

Figure 2.3: Changes in body mass distribution between from the Pleistocene to the Anthropocene. The two big panels on the top represent the proportion of species changes in each size bin of 0.2 units, between Pleistocene and Holocene (left) and Holocene and Anthropocene (right). Curves were drawn to clarify the pattern based on a kernel smoothing. Colors represent each geographical area. The six botton panels show the best model fitted to global data and each of the continents. Different line types represent each time slice analysed here.

the latter (Figure 2.2; Table 2.2).

Although a bimodal distribution has been proposed to be the best way to describe body mass distribution of some terrestrial mammals assemblages (Alroy, 1998, 2003; Lovegrove \& Haines, 2004; Lyons et al., 2004; Kelt \& Meyer, 2009; Smith \& Lyons, 2011; Lyons \& Smith, 2013), we are unaware of any previous work that has explicitly fitted different distribution models for each continent separately (but see Lovegrove \& Haines, 2004, for a comparison between Africa and North America) and compared 
with the global distribution at different points in time. We adopted an approach of model comparison that allow us to explicitly test two hypothesis (bimodal vs. unimodal skewed) and evaluate the likelihood attributed to each one by means of AIC values. There are other tests to detect multimodality but they are not as straight foward as the approach taken here. For example, one of the tests used by Lovegrove \& Haines (2004) was the Silverman's test of multimodality, which yielded confusing results since both unimodality and bimodality could not be rejected based on the observed p-values. Our approach on the other ahnd could provide helped to clarify the observed pattern and is explicit in quantifying the location and shape of the body mass distribution.

It is important to note that we tested just two alternative models to describe the body mass distribution of mammals. Many other possibilities exist and have already been proposed (revised in Allen et al., 2006). For the sake of simplicity we chose to examine two models that describe the two hypotheses that are more often discussed in the literature. Furthermore we explored only one model possibility for each hypothesis proposed, but there are other models that could also be used to describe a unimodal skewed distribution (e.g. Beta distribution) or even other mixtures of functions that could yield a bimodal pattern. We believe that the two models we chose are sufficient to provide us a general picture of how the body mass distribution differs between continents and changed over time, given that those capture broad differences (unimodal vs. bimodal) which are more likely to be relevant and informative than smaller differences between each one of those two categories (e.g. different unimodal distribtuions). In spite of model choice, the fitting of phenomenological patterns is not enough to fully understand the underlying processes that determine the shape and the changes in the mammal body mass distribution. It has been recently proposed that for mammals there are different evolutionary body mass optima associated with different diets (carnivore, omnivore and herbivore - Price \& Hopkins, 2015). Also locomotory strategies were suggested to explain body mass distribution of mammals (Lovegrove \& Haines, 2004). These authors suggested that fast carnivores would impose an upper limit in the body size of plantigride ground dwelling species (e.g. rodents), and require large body size of unguligrade that could run to escape predators. It is likely that multiple ecological factors other than diet and locomotory strategies act in shaping the body mass distribution in mammals over space and time. The influence of ecological interactions (e.g. Character displacement - Dayan \& Simberloff, 2005) and adaptations to environmental conditions (e.g. Bergmans Rule - Gaston \& Blackburn, 2000) have been thoroughly studied and are suggested to influence species body mass. Thus finding a sole explanation for the shape of body mass distribution is unlikely. Here we showed how idiosyncrasies of different continents contribute to the global pattern and our results suggest that there might be indeed different underlying phenomena acting to shape the body mass distribution 
on each continent.

\subsubsection{The effect of Pleistocene extinction}

The loss of the megafauna at the end of the Pleistocene and its effect on the body mass distribution in terrestrial mammals has attracted the attention of many ecologists, paleontologists and evolutionary biologists. The loss of large animals clearly changed the body mass distributions, resulting in changes in ecological dynamics through cascading effects (Gill, 2014; Dirzo et al., 2014). In fact today there are clear evidences that the loss of top predators (usually with large body masses), might trigger considerable changes down the food chain and change ecosystems function and structure (Estes et al., 2011; Ripple et al., 2014). Although the loss of large animals is not a novelty on itself, fitting different models and exploring the changes in parameter estimates give us an important quantitative understanding on how that extinction event shaped the body mass distribution at global and continental scales. Our statistical analysis at global scale confirmed the previously suggested bimodal distribution of body masses for the Pleistocene (Smith \& Lyons, 2011; Lyons \& Smith, 2013). As expected, our results suggest that the effect of Pleistocene extinctions was stronger on the second mode location and the variance around it (compare the Pleistocene and Holocene lines on Figure 2.3). More importantly, megafauna extinction had different effects on the body mass distribution depending on the continent.

The late Pleistocene extinction was less severe on Eurasia and Africa, and we currently observe megafauna in these continents, including megaherbivores weighting more than $1000 \mathrm{Kg}$. This is clear when we compare the distributions of body mass at the Pleistocene and the Holocene (Figure 2.3). We see very little change on body mass distributions for those two continents from the Pleistocene into the Holocene (Figure 2.3 ) and this is reflected in our model selection approach (Table 2.2). Therefore, our statistical analysis of body mass distribution is in accordance with previous suggestions that Eurasia and Africa have not really suffered much during the Pleistocene extinction (Smith \& Lyons, 2011). If we assume that body mass is a good proxy for ecology, we suppose that Pleistocene extinctions had a smaller effect on ecological communities in Eurasia and Africa than in other continents.

Even though Australia was the continent that suffered the strongest megafauna extinction (Koch \& Barnosky, 2006), our results indicate that this drastic loss in biodiversity did not change the overall shape of the body mass distribution from the Pleistocene to the Holocene (Table 2.2). Prior and after the Pleistocene extinction event Australia showed a bimodal body mass distribution. However, when directly comparing the Pleistocene and Holocene body mass distributions for Australia (Figure 2.3) we 
see considerable differences. Since the largest species such as Diprotodon optatum and Procoptodon goliah, did not make into de Holocene, the second mode of the bimodal distribution decreased considerably (Table 2.3). Australian mammal assemblages in the Holocene are dominated by smaller species such as medium-sized macropods and small-sized dasyuromorphs, which implies in very different ecological dynamics when compared to the Pleistocene. For instance, the increase in frequency of fires and the change from rainforest to sclerophyll vegetation in Australia have been related to the demise of the megafauna (Rule et al., 2012). For Australia, the persistence of a bimodal pattern is strongly influenced by the relative low frequency of species from 200 to $900 \mathrm{~g}$ (between 2 and 3 in $\log _{10}$ scale - Figure 3) and relatively high abundance of species at the range $1 \mathrm{Kg}$ and $10 \mathrm{~kg}$ (between 3 and 4 in $\log _{10}$ scale - Figure 2.3). Hence the loss of large animals does not necessarily translate into the loss of a bimodal distribution for all different continents. It is an open question how the loss of those larger animals in Australia might have percolated down in the ecological networks.

North America, on the other hand, was the only continent that indeed changed from a bimodal to a unimodal distribution on body mass after the Pleistocene extinction (Table 2.2). Interestingly, this change seems to be only partially driven by the loss of the Megafauna. Prior to the North American megafauna extinction the distribution comprised by large species (the second mode) showed the highest mean and variance of all continents, but the lowest contribution to the bimodal pattern (Table 2.3). The low contribution of the second mode is in part due to the low density of species weighting between $1 \mathrm{Kg}$ and $30 \mathrm{Kg}$, at least when compared to the body mass distribution of other continents (Figure $2.2 \& 2.3$ ). Thus the effect of megafauna extinction, which removed the tail of the distribution, combined with the already low density of medium to large species was responsible for changing the observed pattern to unimodality. We should note that some intermediate-sized (around $1 \mathrm{Kg}$ ) species present in North America dataset belong to lineages that are known to have a South American origin. In fact in our analysis we used the MOM dataset, which considers Central America and North America to be one region. However, it has been suggested that Central America is a transitional biogeographic region (Kreft \& Jetz, 2013) that is strongly influenced by both North and South America, and that acted as the bridge that propitiated the Great American Biota Exchange (Woodburne, 2010). Therefore it is possible that the North American body size distribution depicted here has a stronger influence from South American than would be observed in case a different biogeographic definition was used. Therefore the change towards an unimodal distribution in the Holocene, and to some extent the less pronounced second mode in the Pleistocene, might also have been affected by the Great American Biota Exchange. This proposition is supported by the empirical observation that North American mammals had a bimodal distribution for 
most of its last 40My of history (Alroy 1998).

The body size distribution in South America was better fitted by the Skew Normal distribution at all time periods (Figure 2.2; Table 2.2), even though the shape of the distribution changed over time (Figure 2.3). Contrary to previous proposition (Lyons \& Smith, 2013), these results suggest that the lack of bimodality observed today is not related to the megafauna extinction. Additionally, it suggests that the processes that have governed body mass evolution in this continent were probably different from other continents. We believe that the skewed unimodal distribution of South America data is highly explained by the elevated richness of intermediate-sized species, between $100 \mathrm{~g}$ and $3100 \mathrm{~g}$ (2 and 3.5 in $\log _{10}$ scale Figure 2.1). Interestingly, these species occupy the position of the body mass axis where a valley is observed in the bimodal distribution of other continents. Moreover, these species probably hamper the visualization of a valley on the global distribution of terrestrial mammals. Indeed, (Marquet \& Cofre, 1999) showed that the elevated number of intermediate-sized species is one of the main differences between the body mass distribution of South America and North America. Those authors compared these two continents only, but our analysis suggested that the presence of intermediate-sized species make South America a unique continent that differs from all other continents and from the global pattern. During the Cenozoic, South America was isolated for a long period of time (since its split from Antarctica until the Panamanian Isthmus closure - Wilf et al., 2013) and this isolation lead to the evolution of a unique fauna. The vast majority of these intermediate size species belong to four groups: Orders of Marsupial and Xenarthra that occupied the continent before the break up of Gondwana (Springer et al., 2011); and the Platyrrhini monkeys and Caviomorph rodents that migrated from Africa to South America around 40Mya (Antoine et al., 2012; Bond et al., 2015). Thus, there might be an evolutionary explanation for the differential pattern observed in South America. It is interesting to note that most species in those groups (thus intermediate-sized) in South America are arboreal. Foraging in the canopy is a locomotory strategy that evolved independently for different groups but is often associated with specific morphological adaptations related to improving balance and adherence (Hildebrand, 1982). Also the weight supported by tree branches imposes a constraint against large body sizes. On the other hand, an arboreal habit may provide access to multiple resources (e.g. fruits and leafs - Hildebrand, 1982) as well as protection against fast cursorial predators (Lovegrove \& Haines, 2004). The large number of arboreal species is expected given the vast tropical forests found in South America (Olson et al., 2001). The presence of groups that were able to diversify in an arboreal habitat, and the prevalence of forested habitats, may have favored the intermediate-sized species in South America.

Taken together, the results from the Pleistocene extinction event suggest that the 
minor changes observed in the global distribution hide the fact that some continents were more strongly affected than others. Although the megafauna extinction did not change the body mass distribution for the Eurasian or the African continents, it drastically changed the body mass distribution of North American terrestrial mammals. Even though there were meaningful changes in South American and Australian body mass distributions, the best fitting model is the same between the Pleistocene and Holocene. After the megafauna extinction Australia remained bimodal due to a pronounced low density of intermediate-sized species. On the other hand, a high density of intermediatesized species in South America hinders a bimodal pattern in the body mass distribution.

\subsubsection{The Anthropocene projection}

Our Anthropocene projections suggest that at a global scale the body mass distribution will not suffer a great qualitative change if the current endangered species become extinct (Figure $2.2 \&$ Figure 2.3), it will remain a bimodal distribution. More importantly it suggests that the effects of the Anthropocene extinctions on body mass distributions, as simulated here, are unlikely to reach the magnitude of the Pleistocene extinction event. Yet, although the effect of Pleistocene extinctions was stronger on the second mode location and the variance around it, the effect on the contribution of large species (parameter $a$ on Table 2.3) to the global pattern was small (from $48 \%$ to $47 \%$ ). The opposite is observed for the Anthropocene scenario analyzed here. After removing all threatened species the body mass distribution suffers minor changes in location and variance on the second normal distribution but the amount of species around the second mode is considerably diminished (from $47 \%$ to $42 \%$ - Table 2). These differences arise from distinct extinction biases in the Pleistocene and in the Anthropocene. While the megafauna (species larger than $44.5 \mathrm{Kg}$ ) were particularly vulnerable in the Pleistocene and are still the most threatened species in the ongoing biodiversity crisis (Figure 2.3 top panels), current crisis will have a considerable impact on other body mass categories. The potential extinction events considered for the Anthropocene also include many species that belong to the second mode, those between $3 \mathrm{Kg}$ and $44.5 \mathrm{Kg}$ (Figure 2.3; see also Cardillo et al., 2005). Also, a larger proportion of species are now considered threatened than the amount of extinctions that occurred in the Pleistocene (Table 2.1).

Interestingly our projection suggests that the Anthropocene extinctions will affect each continent in different ways. The body mass distribution of North American terrestrial mammals is unlikely to change much, remaining unimodal and quantitatively similar even if all threatened species die out (Table 2.3). Different from other continents extinction risk in North America is almost uniform across the different body size classes 
(Figure 2.3 - top right panel). Similarly the body mass distribution in South America is unlikely to suffer great qualitative or quantitative changes due to the Anthropocene projected extinctions. However, North American and South American mammalian faunas are still condemned to be largely depleted in the near future. The number of threatened mammals is 76 for North America and 104 for South America, which represents 15.7\% and $15.8 \%$ of the North and South American mammals, respectively. These losses will reduce the functional redundancy of natural systems considerably and the results can be dire, as already seem in many regions (e.g., Estes 2011; Dirzo 2014).

Australia shows a remarkably different pattern. Our results suggest that Australia is likely to experience a disproportional loss of species weighting around 300g (Figure 2.3). All of Australia's largest species went extinct during the late Pleistocene, and now the endangered species there show a completely different pattern when compared to other continents (Figure 2.3). This particular trend is probably related to the differences in the threats suffered by the Australian mammalian fauna. In most continents hunting and habitat loss are the main threats to terrestrial mammals, affecting mainly largebodied species, which have large home ranges and resource requirements (Redford, 1992; Galetti \& Dirzo, 2013). However, most endangered species in Australia occur in remote areas and the main threats faced by these species are predation by introduced species, specially small and medium-sized predators such as feral cats (Felis cattus) and the red fox (Vulpes vulpes; Woinarski et al., 2015). This bias towards smaller-sized species imposes an extinction pattern that goes in the opposite direction expected for other continents. This contradicts the long-lasting idea that large species are always more prone to extinction and shows that extinctions are highly context-dependent.

Africa and Eurasia show the most striking prognosis. These continents retained a considerable amount of their large-bodied mammals after the Pleistocene. However the losses that might be experienced in the near future will, most likely, have a significant impact in body mass distributions, reducing the numbers of large-bodied mammals (Fritz et al., 2009). This effect is expected to be more pronounced in Eurasia, where most species larger than $10 \mathrm{Kg}$, such as Elephas maximus and Rhinoceros sondaicus are considered endangered today. This suggests Pleistocene extinctions, as well as their consequences (Gill, 2014), have been protracted to the present in these continents. 


\section{Discussão Geral}

Nesse trabalho foi utilizada uma abordagem macroecológica para investigar como processos em diferentes escalas espaciais poderiam afetar a ocupação do nicho e a relação dessa ocupação com a riqueza de espécies. De forma simplificada, poderíamos esperar que um aumento da riqueza de espécies poderia ocorrer por um empacotamento dos nichos, por uma expansão do espaço de nicho total ou uma combinação das duas coisas. O objetivo desse trabalho foi investigar se fatores históricos ou mesmo regionais poderiam afetar a relação entre disparidade ecológica e riqueza de espécies.

Para realizar um estudo com essa magnitude geográfica é necessária a caracterização do nicho de diversas espécies, o que é uma tarefa muito complicada. No presente estudo utilizamos o tamanho corpóreo como um aproximação do nicho de mamíferos uma vez que dados dessa natureza são conhecidos para virtualmente todos os mamíferos (Wilman et al., 2014). Apesar de parecer uma forma rudimentar de caracterizar o nicho, o uso de massa corpórea vem sendo utilizado para descrever a ecologia de animais pois a massa está correlacionada com muitos características metabólicas, fisiológicas e comportamentais dos indivíduos (Bonner, 2011).

A utilização de uma característica tão abrangente deve ser usada com cuidado, e por isso descartamos os dados referentes aos morcegos pois é conhecido que as adaptações ao voo restringem significativamente o tamanho corpóreo. Ademais esse grupo tem uma considerável sobreposição de massa com outras linhagens de mamíferos terrestres que tem ecologias muito distintas. De fato para a grande parte dos mamíferos terrestres, a massa corpórea está correlacionada com diferentes hábitos de vida e pode ser vista como um balanço entre pressões seletivas atuando em adaptações internas dos organismos e nas suas interações com o meio ambiente (Marquet et al., 2008).

Ao avaliar duas escalas geográficas (pool global e pool regional), o principal resultado deste trabalho foi identificar diferenças significativas na ocupação do morfoespaço entre a America do Sul e o resto do mundo. A diferença mais basal se deve à presença de muitas espécies de tamanho intermediário (entre $200 \mathrm{~g}$ e $1 \mathrm{~kg}$ ). A elevada riqueza dessas espécies faz com que a distribuição de massa da América do Sul seja unimodal com uma longa cauda, e diferentemente do esperado (Smith \& Lyons, 2011), a inclusão das espécies da megafauna não muda esse padrão (Capítulo 2). É interessante notar que a grande maioria das espécies de tamanho intermediário pertencem a quatro grupos: Ordens de Marsupial e de Xenarthra que estão presentes no continente anteriormente à separação da Gondwana (Springer et al., 2011); os macacos Platyrrhini e roedores caviomorfos que provavelmente migraram da Africa para a América do Sul por volta de 40 milhões de anos atrás, apesar da rota dessa migração ainda ser um motivo de grande debate 
(Antoine et al., 2012; Bond et al., 2015). Uma grande proporção das espécies desses grupos apresentam hábitos arborícolas, uma estratégia de forrageamento que requer inúmeras adaptações morfológicas que permitem um melhor equilíbrio e aderência aos galhos das árvores (Hildebrand, 1982). Além disso o peso suportado pelos galhos das árvores parece impor uma restrição ao tamanho máximo para otimizar a locomoção em árvores (Hildebrand, 1982). Desta forma sugerimos que a presença de algumas linhagens que ficaram isoladas no continente, associados com uma ampla cobertura florestal que já persiste há milhões de anos no continente (Fine \& Ree, 2006) deve ter sido responsável pela grande diversificação de espécies arbóreas com um tamanho de corpo restrito.

Sugerimos também que a elevada riqueza de espécies intermediárias resulta em assembleias locais com evidência de empacotamento de nicho nos Neotrópicos (Capítulo 1). As medidas Média das Distância par-a-par (MD) e Taxa de participação (PR) assumiram valores baixos nessa região, e mais importante, menores do que seria esperado dada a riqueza de espécies das assembleias. Esses resultados sugerem um acúmulo de espécies em regiões específicas do morfoespaço. Dado que há um "vale" na distribuição de massa da maioria dos continentes, exatamente nas categorias de tamanho intermediário, grande parte da diferença das assembleias locais da América do Sul, em relação ao restante do globo, se deve a presença dessas espécies arbóreas de tamanho intermediário. Os Neotrópicos ainda apresentam uma outra diferença marcante em relação aos outros continentes que é a baixa riqueza de espécies muito pequenas. Sugerimos que dois motivos principais seriam responsáveis por esse padrão. Primeiro poderiam haver restrições evolutivas que impediram os grupos presentes na América do Sul de ocupar esse nicho. Segundo, a colonização de linhagens com representantes de tamanho muito pequeno teria sido impossibilitada no continente Sul Americano. No primeiro caso é necessário que as linhagens que compõem a biota sulamericana apresentem tais restrições evolutivas. Como somente alguns grupos de mamíferos apresentam tamanhos muito pequenos de corpo (Soricomorpha e Afroscoricida), esses grupos não se encontram na América do Sul, e a evolução de tamanho de corpo muito pequeno não parece ser trivial do ponto de vista fisiológico (Smith et al., 2004) é possível que a ausência inicial de um estoque evolutivo capaz de gerar mamíferos terrestres muito pequenos esteja relacionada com essa ausência de mamíferos terrestres muito pequenos na América do Sul. Explicar a incapacidade de migração de espécies muito pequenas a princípio parece complicado, mas é possível que a geografia do continente Sulamericano, em particular o surgimento dos Andes, tenham impedido a entrada de linhagens com espécies muito pequenas. Também é possível que tal limitação decorra de interações ecológicas, como competição ou mesmo predação e parasitismo, impedindo o estabelecimento dessas espécies na América do Sul, porém esses mecanismo parecem pouco plausíveis.

O significado ecológico de assembleias mais "empacotadas" é difícil de ser avaliado so- 
mente com dados de tamanho de corpo e com uma abordagem geograficamente ampla, porém nossos resultados propõem hipóteses interessantes que poderiam ser eventualmente testadas com outras abordagens. De um lado poderíamos argumentar que por apresentarem uma maior concentração de espécies em alguns pontos do morfoespaço assembleias sul-americanas estariam mais sujeitas a competição inter-específica. Por outro lado é possível que essas espécies se diferenciem em outros aspectos do nicho aqui não investigados. Dado que grande parte dessa concentração ocorre em espécies arborícolas é possível que tais espécies estejam sofrendo mais competição inter-específica ou que tenham se diferenciado estratigraficamente nas árvores ou em dieta. Além disso poderíamos argumentar que o maior adensamento de espécies em algumas partes do morfoespaço poderia justamente significar menor intensidade de competição inter-específica nos Neotrópicos, uma vez que esse maior adensamento significa uma sobreposição de nicho com um número maior de espécies, o que só seria possível em caso de baixa competição. Entender o mecanismo responsável pelo empacotamento das assembleias sul-americanas é uma tarefa difícil, mas os nossos resultados claramente sugerem que processos que atuam em um escala regional são de primordial importância em determinar como o morfo-espaço e riqueza de espécies se relaciona.

A abordagem proposta aqui também nos permitiu investigar como a ocupação do morfo-espaço de mamíferos terrestres em diferentes continentes responderam ou responderão à extinções passadas e potenciais extinções futuras. Por mais que seja possível avaliar as espécies viventes em escalas geográficas finas, como feito no capítulo 1, há uma grande dificuldade em se obter dados de distribuição geográfica para espécies fósseis, apesar do grande esforço científico em busca de tais reconstruções (p.ex. Lima-Ribeiro \& Diniz-Filho, 2013; Faurby \& Svenning, 2015). Por outro lado a composição atual de espécies e os padrões atuais de diversidade certamente foram afetados por eventos históricos. Por exemplo, sabemos que mudanças climáticas em conjunto com a chegada dos humanos pode ter levado a extinção de espécies da megafauna que só conhecemos por meio do registro fóssil (Koch \& Barnosky, 2006). Desta forma em primeiro lugar buscamos entender como a extinção da megafauna no final do Pleistoceno afetou as distribuições de massa nos diferentes continentes. Posteriormente buscamos comparar se o efeito da extinção do final do Pleistoceno pode ser comparada com um possível efeito antrópico, e verificar se existem diferenças significativas entre os diferentes continentes. Nossas análises sugerem que apesar da África e da Eurásia não terem sido muito afetadas durante o a extinção do Pleistoceno, a perda das espécies ameaçadas nesses continentes irá acarretar uma mudança na distribuição de massa similar aquela experimentada pelos outros continentes durante as extinções do Pleistoceno. Por outro lado os outros continentes (Américas e Australia) não irão sofrer grandes alterações na distribuição de massa apesar de perderem uma proporção elevada de espécies caso as 
extinções previstas para o Antropoceno se concretizem. Desta forma nossos resultados sugerem que os potenciais impactos atribuídos à civilização moderna poderiam alterar significativamente as distribuições geográficas das espécies, influenciar os padrões espaciais de disparidade e riqueza de espécies que reportamos no Capítulo 1, mas que essas alterações não serão iguais no globo como um todo. 


\section{Resumo}

Entender a relação entre riqueza de espécies e diversidade de nichos ecológicos pode auxiliar a compreensão dos diferentes processos que governam a coexistência de espécies. Caracterizar o nicho de diversas espécies não é trivial, e o nicho é frequentemente estudado a partir de características morfológicas. A massa corpórea está relacionada com características metabólicas, fisiológicas, comportamentais e ecológicas das espécies e então é ideal para estudos ecológicos que envolvem muitas espécies e localidades.

Em teoria, um aumento na riqueza de espécies poderia ocorrer tanto pela expansão do espaço de nicho total, quanto pelo empacotamento de nicho, ou mesmo por uma combinação de ambos. Neste trabalho utilizamos massa corpórea de mamíferos terrestres para investigar a ocupação do morfoespaço e a relação dessa ocupação com a riqueza de espécies tanto em assembleias locais, quanto em biotas continentais.

No primeiro capítulo desta dissertação, investigamos a variação espacial da disparidade morfológica de mamíferos terrestres e sua relação com a riqueza de espécies. Utilizamos os dados de distribuição geográfica de 4146 espécies para determinar a composição de assembléias locais em um grid com células com $1^{\circ}$ de lado. Para cada assembleia, calculamos quatro medidas de disparidade morfológica utilizando massa corpórea como um descritor da morfologia de mamíferos. Comparamos as medidas de disparidade de cada célula com o que seria esperado de acordo com dois modelos nulos (um global e outro regional) que diferem em relação ao pool utilizado para reamostragem.

No segundo capítulo, investigamos o efeito da extinção da megafauna e os possíveis efeitos das extinções atuais na distribuição de massa de mamíferos terrestres. De acordo com trabalhos anteriores a distribuição de massa de mamíferos tornou-se bimodal 40 milhões de anos atrás e assim se manteve até o final do Pleistoceno, quando foi modificada pela extinção da megafauna, tornando-se unimodal. Ajustamos dois modelos concorrentes (bimodal e unimodal assimétrico) às distribuições de massa corpórea dos mamíferos de todo o globo e de cada continente separadamente em três momentos de tempo: Final do Pleistoceno, Holoceno e Antropoceno.

Os resultados obtidos nos dois capítulos, apesar de observados em escalas muito distintas, sugerem um padrão de empacotamento de nichos nos Neotrópicos. Esse padrão não é influenciado pela extinção da megafauna, e se deve à diversificação de grupos específicos no continente sul americano. Grande parte das espécies dos grupos endêmicos são arborícolas sugerindo a importância das florestas tropicais na diversificação de mamíferos desse continente. Nossos resultados também sugerem que a perda das espécies ameaçadas de extinção no Antropoceno irão resultar em mudanças significativas na África e na Eurásia, dois continentes menos afetados pelas extinções do Pleistoceno. 



\section{Abstract}

Understand the relation between species richness and ecological niche diversity might help to understand processes behind species coexistence. However, to quantify species niche is not easy and a ecomorfological approach is often used instead. Body mass is related to several life history traits such as metabolism, physiology, behaviour and ecology, thus being the ideal trait for studies comparing many different species and localities.

In theory, increases in species richness could be attained by an expansion of total niche space or by niche packing, or even by a combination of both. Here we use terrestrial mammals body mass to investigate morphospace occupation and its relation to species richness in both local assemblages and continental biotas.

In the first chapter, we investigate the spatial variation of morphological disparity of terrestrial mammals and its relation to species richness. We used species distributions of 4146 species to determine the composition of local assemblages in a grid of $1^{\circ}$ cells. For each assemblage we measured four morphological disparity metrics using body mass as a surrogate of mammalian morphology. We compared the observed disparity measures for each cell with the expected distribution given by two null models (one global and other regional) that differ for the species pool used to perform resamples.

In the second chapter we investigated the effect of megafauna extinctions and possible effects of ongoing extinctions on the body mass distribution of terrestrial mammals. Previous studies suggest that the body mass distribution of mammals became bimodal 40 millon years ago and so remained until the end of the Pleistocene, when it was modified by megafauna extinction and became unimodal. We fitted two concurrig models (a bimodal and a skewed unimodal) to the body mass distribution of global mammals and of each continent separately in tree time frames: Late Pleistocene, Holocene and Anthropocene.

The results from both chapters, although from observation in different scales, suggest a pattern of niche packing on the Neotropics. This pattern is not biased by the recent megafauna extinction, but is due to the diversification of clades specific to the south american continent during its period of isolation. A high proportion of the species in this endemic groups is arboreal suggesting the importance of tropical forests in the diversification of mammals in this continent. Our results also suggest that the possible loss of endangered species in the Anthropocene will result in meaningful changes in Africa and Eurasia, two continents that where less affected by Pleistocene extinctions. 



\section{Bibliography}

Allen, C. R., A. S. Garmestani, T. D. Havlicek, P. A. Marquet, G. D. Peterson, C. Restrepo, C. A. Stow, \& B. E. Weeks, 2006. Patterns in body mass distributions: sifting among alternative hypotheses. Ecol Lett 9:630-43.

Alroy, J., 1998. Cope's rule and the dynamics of body mass evolution in north american fossil mammals. Science 280:731-734.

, 2003. Taxonomic inflation and body mass distributions in north american fossil mammals. Journal of mammalogy 84:431-443.

Antoine, P.-O., L. Marivaux, D. A. Croft, G. Billet, M. Ganerød, C. Jaramillo, T. Martin, M. J. Orliac, J. Tejada, A. J. Altamirano, F. Duranthon, G. Fanjat, S. Rousse, \& R. S. Gismondi, 2012. Middle eocene rodents from peruvian amazonia reveal the pattern and timing of caviomorph origins and biogeography. Proc Biol Sci 279:131926.

Azzalini, A., 2015. The Skew-Normal and Skew-t Distributions. R Foundation for Statistical Computing.

Bacon, C. D., D. Silvestro, C. Jaramillo, B. T. Smith, P. Chakrabarty, \& A. Antonelli, 2015. Biological evidence supports an early and complex emergence of the isthmus of panama. Proc Natl Acad Sci U S A 112:6110-5.

Barnosky, A., N. Matzke, S. Tomiya, G. Wogan, B. Swartz, T. Quental, C. Marshall, M. Jenny, E. Lindsey, K. Maguire, B. Mersey, \& E. Ferrer, 2011. Has the earth's sixth mass extinction already arrived? Nature 471:51-57.

Benton, M. J., 2015. Exploring macroevolution using modern and fossil data. Proceedings of the Royal Society of London B: Biological Sciences 282:20150569.

Blackburn, T. M. \& K. J. Gaston, 1994. Animal body size distributions: patterns, mechanisms and implications. Trends in Ecology \& Evolution 9:471-474.

Blackburn, T. M., K. J. Gaston, \& N. Loder, 1999. Geographic gradients in body size: a clarification of bergmann's rule. Diversity and distributions 5:165-174.

Bolker, B. M., 2008. Ecological models and data in R. Princeton University Press.

Bolnick, D. I. \& M. Doebeli, 2003. Sexual dimorphism and adaptive speciation: two sides of the same ecological coin. Evolution 57:2433-2449.

Bond, M., M. F. Tejedor, K. E. Campbell, Jr, L. Chornogubsky, N. Novo, \& F. Goin, 2015. Eocene primates of south america and the african origins of new world monkeys. Nature 520:538-41.

Bonner, J. T., 2011. Why size matters: from bacteria to blue whales. Princeton University Press.

Brown, J. H., 2014. Why are there so many species in the tropics? J Biogeogr 41:8-22. 
Brown, J. H., J. F. Gillooly, A. P. Allen, V. M. Savage, \& G. B. West, 2004. Toward a metabolic theory of ecology. Ecology 85:1771-1789.

Brown, J. H., P. A. Marquet, \& M. L. Taper, 1993. Evolution of body size: consequences of an energetic definition of fitness. American Naturalist Pp. 573-584.

Brown, J. H. \& B. A. Maurer, 1989. Macroecology: the division of food and space among species on continents. Science 243:1145-1150.

Brown, J. H. \& P. F. Nicoletto, 1991. Spatial scaling of species composition: body masses of north american land mammals. American Naturalist Pp. 1478-1512.

Buckley, L. B., T. J. Davies, D. D. Ackerly, N. J. Kraft, S. P. Harrison, B. L. Anacker, H. V. Cornell, E. I. Damschen, J.-A. Grytnes, B. A. Hawkins, et al., 2010. Phylogeny, niche conservatism and the latitudinal diversity gradient in mammals. Proceedings of the Royal Society B: Biological Sciences 277:2131-2138.

Cardillo, M., G. M. Mace, K. E. Jones, J. Bielby, O. R. Bininda-Emonds, W. Sechrest, C. D. L. Orme, \& A. Purvis, 2005. Multiple causes of high extinction risk in large mammal species. Science 309:1239-1241.

Ciampaglio, C. N., M. Kemp, \& D. W. McShea, 2001. Detecting changes in morphospace occupation patterns in the fossil record: Characterization and analysis of measures of disparity. Paleobiology 27:pp. 695-715.

Connell, J. H., 1961. The influence of interspecific competition and other factors on the distribution of the barnacle chthamalus stellatus. Ecology 42:710-723.

Cornell, H. V., 1985. Local and regional richness of cynipine gall wasps on california oaks. Ecology Pp. 1247-1260.

Cornell, H. V. \& S. P. Harrison, 2014. What are species pools and when are they important? Annual Review of Ecology, Evolution, and Systematics 45:45-67.

Currie, D. J., G. G. Mittelbach, H. V. Cornell, R. Field, J.-F. Guégan, B. A. Hawkins, D. M. Kaufman, J. T. Kerr, T. Oberdorff, E. O'Brien, et al., 2004. Predictions and tests of climate-based hypotheses of broad-scale variation in taxonomic richness. Ecology letters 7:1121-1134.

Darwin, C., 1859. The origin of species by means of natural selection: or, the preservation of favored races in the struggle for life.

Dayan, T. \& D. Simberloff, 2005. Ecological and community-wide character displacement: the next generation. Ecology Letters 8:875-894.

De Vivo, M. \& A. P. Carmignotto, 2004. Holocene vegetation change and the mammal faunas of south america and africa. Journal of Biogeography 31:943-957.

Dirzo, R., H. S. Young, M. Galetti, G. Ceballos, N. J. Isaac, \& B. Collen, 2014. Defaunation in the anthropocene. Science 345:401-406. 
Elton, C., 1946. Competition and the structure of ecological communities. The Journal of Animal Ecology Pp. 54-68.

Estes, J. A., J. Terborgh, J. S. Brashares, M. E. Power, J. Berger, W. J. Bond, S. R. Carpenter, T. E. Essington, R. D. Holt, J. B. Jackson, et al., 2011. Trophic downgrading of planet earth. science 333:301-306.

Faurby, S. \& J.-C. Svenning, 2015. Historic and prehistoric human-driven extinctions have reshaped global mammal diversity patterns. bioRxiv .

Fine, P. \& R. Ree, 2006. Evidence for a time-integrated species-area effect on the latitudinal gradient in tree diversity. The American naturalist 168:796-804.

Foote, M., 1992. Paleozoic record of morphologica diversity in blastozoan echinoderms. Proceedings of the National Academy of Sciences 89:7325-7329.

- 1993. Discordance and concordance between morphological and taxonomic diversity. Paleobiology 19:pp. 185-204.

- 1997. The evolution of morphological diversity. Annual Review of Ecology and Systematics 28:pp. 129-152.

Fritz, S. A., O. R. Bininda-Emonds, \& A. Purvis, 2009. Geographical variation in predictors of mammalian extinction risk: big is bad, but only in the tropics. Ecology letters 12:538-549.

Galetti, M. \& R. Dirzo, 2013. Ecological and evolutionary consequences of living in a defaunated world. Biological Conservation 163:1-6.

Gaston, K. \& T. Blackburn, 2000. Pattern and Process in Macroecology. Wiley.

Gill, J. L., 2014. Ecological impacts of the late quaternary megaherbivore extinctions. New Phytologist 201:1163-1169.

Gwynne, M. \& R. Bell, 1968. Selection of vegetation components by grazing ungulates in the serengeti national park .

Hildebrand, M., 1982. Analysis of vertebrate structure. Wiley.

Hillebrand, H., 2004. On the generality of the latitudinal diversity gradient. The American naturalist 163:192-211.

Holt, B. G., J.-P. Lessard, M. K. Borregaard, S. A. Fritz, M. B. Araújo, D. Dimitrov, P.-H. Fabre, C. H. Graham, G. R. Graves, K. A. Jønsson, et al., 2013. An update of wallace's zoogeographic regions of the world. Science 339:74-78.

Huang, S., P. R. Stephens, \& J. L. Gittleman, 2012. Traits, trees and taxa: global dimensions of biodiversity in mammals. Proceedings of the Royal Society B: Biological Sciences 279:4997-5003.

Hubbell, S. P., 2001. The unified neutral theory of biodiversity and biogeography, vol. 32. Princeton University Press. 
Hurlbert, A. H. \& J. C. Stegen, 2014. When should species richness be energy limited, and how would we know? Ecol Lett 17:401-13.

Hutchinson, G., 1957. Concluding remarks .

Hutchinson, G. \& R. MacArthur, 1959. A theoretical ecological model of size distributions among species of animals. American Naturalist Pp. 117-125.

IUCN, 2012. Iucn red list. URL http://www. iucnredlist.org/.

Jablonski, D., K. Roy, \& J. Valentine, 2006. Out of the tropics: evolutionary dynamics of the latitudinal diversity gradient. Science (New York, N.Y.) 314:102-106.

Kelt, D. A. \& M. D. Meyer, 2009. Body size frequency distributions in african mammals are bimodal at all spatial scales. Global Ecology and Biogeography 18:19-29.

Koch, P. L. \& A. D. Barnosky, 2006. Late quaternary extinctions: state of the debate. Annual Review of Ecology, Evolution, and Systematics Pp. 215-250.

Kozłowski, J., A. Gawelczyk, et al., 2002. Why are species' body size distributions usually skewed to the right? Functional Ecology 16:419-432.

Kreft, H. \& W. Jetz, 2013. Comment on "an update of wallace's zoogeographic regions of the world". Science 341:343-343.

Legendre, P., 1993. Spatial autocorrelation: trouble or new paradigm? Ecology 74:16591673.

Lessard, J.-P., J. Belmaker, J. A. Myers, J. M. Chase, \& C. Rahbek, 2012. Inferring local ecological processes amid species pool influences. Trends in ecology \& evolution 27:600-607.

Levin, S. A., 1992. The problem of pattern and scale in ecology: the robert h. macarthur award lecture. Ecology 73:1943-1967.

Lima-Ribeiro, M. S. \& J. A. F. Diniz-Filho, 2013. American megafaunal extinctions and human arrival: improved evaluation using a meta-analytical approach. Quaternary International 299:38-52.

Loreau, M., 2000. Are communities saturated? on the relationship between $\alpha, \beta$ and $\gamma$ diversity. Ecology letters 3:73-76.

Lovegrove, B. G. \& L. Haines, 2004. The evolution of placental mammal body sizes: evolutionary history, form, and function. Oecologia 138:13-27.

Lyons, S. K. \& F. A. Smith, 2013. Macroecological patterns of body size in mammals across time and space; in Animal body size: linking pattern and process across space, time, and taxonomic group, chap. 5. University of Chicago Press.

Lyons, S. K., F. A. Smith, \& J. H. Brown, 2004. Of mice, mastodons and men: humanmediated extinctions on four continents. Evolutionary Ecology Research 6:339-358. 
MacArthur, R. \& R. Levins, 1967. The limiting similarity, convergence, and divergence of coexisting species. American naturalist Pp. 377-385.

Macdonald, D., 2009. The Princeton encyclopedia of mammals. Princeton University Press.

Marquet, P. A., S. Abades, J. E. Keymer, \& H. Zeballos, 2008. Discontinuities in body-size distribution; in Discontinuities in ecosystems and other complex systems. Columbia University Press.

Marquet, P. A. \& H. Cofre, 1999. Large temporal and spatial scales in the structure of mammalian assemblages in south america: a macroecological approach. Oikos Pp. 299-309.

Mathias M. Pires, T. B. Q., Daniele Silvestro, 2015. Continental faunal exchange and the asymmetrical radiation of carnivores. In review .

Maurer, B. A., J. H. Brown, \& R. D. Rusler, 1992. The micro and macro in body size evolution. Evolution Pp. 939-953.

Mittelbach, G. G., D. W. Schemske, H. V. Cornell, A. P. Allen, J. M. Brown, M. B. Bush, S. P. Harrison, A. H. Hurlbert, N. Knowlton, H. A. Lessios, C. M. McCain, A. R. McCune, L. A. McDade, M. A. McPeek, T. J. Near, T. D. Price, R. E. Ricklefs, K. Roy, D. F. Sax, D. Schluter, J. M. Sobel, \& M. Turelli, 2007. Evolution and the latitudinal diversity gradient: speciation, extinction and biogeography. Ecol Lett $10: 315-31$.

Morales-Castilla, I., M. Á. Olalla-Tárraga, A. Purvis, B. A. Hawkins, \& M. Á. Rodríguez, 2012. The imprint of cenozoic migrations and evolutionary history on the biogeographic gradient of body size in new world mammals. Am Nat 180:246-56.

Moreno, C. E., H. T. Arita, \& L. Solis, 2006. Morphological assembly mechanisms in neotropical bat assemblages and ensembles within a landscape. Oecologia 149:133140.

Neige, P., 2003. Spatial patterns of disparity and diversity of the recent cuttlefishes (Cephalopoda) across the old world. Journal of Biogeography 30.

Norberg, U. M., 1994. Wing design, flight performance, and habitat use in bats. Ecological morphology: integrative organismal biology Pp. 205-239.

Nürnberg, S. \& M. Aberhan, 2015. Interdependence of specialization and biodiversity in phanerozoic marine invertebrates. Nat Commun 6:6602.

Olson, D. M., E. Dinerstein, E. D. Wikramanayake, N. D. Burgess, G. V. N. Powell, E. C. Underwood, J. A. D'amico, I. Itoua, H. E. Strand, J. C. Morrison, C. J. Loucks, T. F. Allnutt, T. H. Ricketts, Y. Kura, J. F. Lamoreux, W. W. Wettengel, P. Hedao, \& K. R. Kassem, 2001. Terrestrial ecoregions of the world: A new map of life on earth. BioScience 51. 
Paine, R. T., 1966. Food web complexity and species diversity. American Naturalist Pp. 65-75.

Pires, M. M., M. Galetti, C. I. Donatti, M. A. Pizo, R. Dirzo, \& P. R. Guimarães Jr, 2014. Reconstructing past ecological networks: the reconfiguration of seed-dispersal interactions after megafaunal extinction. Oecologia 175:1247-1256.

Price, S. A. \& S. S. Hopkins, 2015. The macroevolutionary relationship between diet and body mass across mammals. Biological Journal of the Linnean Society 115:173-184.

Redford, K. H., 1992. The empty forest. BioScience Pp. 412-422.

dos Reis, M., J. Inoue, M. Hasegawa, R. J. Asher, P. C. J. Donoghue, \& Z. Yang, 2012. Phylogenomic datasets provide both precision and accuracy in estimating the timescale of placental mammal phylogeny. Proc Biol Sci 279:3491-500.

Ricklefs, R., 2010. Evolutionary diversification, coevolution between populations and their antagonists, and the filling of niche space. Proceedings of the National Academy of Sciences of the United States of America 107:1265-1272.

Ricklefs, R. \& D. Miles, 1994. Ecological and evolutionary inferences from morphology: an ecological perspective. Ecological morphology: integrative organismal biology. University of Chicago Press, Chicago 101:13-41.

Ricklefs, R. E., 1987. Community diversity: relative roles of local and regional processes. Science 235:167-171.

— 2004. A comprehensive framework for global patterns in biodiversity. Ecology Letters $7: 1-15$.

— 2008. Disintegration of the ecological community. Am Nat 172:741-50.

— 2009 . Aspect diversity in moths revisited. The American naturalist 173:411-416.

— 2012. Species richness and morphological diversity of passerine birds. Proc Natl Acad Sci U S A 109:14482-7.

Ricklefs, R. E. \& R. E. Latham, 1993. Global patterns of diversity in mangrove floras. Species diversity in ecological communities: historical and geographical perspectives. University of Chicago Press, Chicago Pp. 215-229.

Ricklefs, R. E. \& K. O'Rourke, 1975. Aspect diversity in moths: A Temperate-Tropical comparison. Evolution 29.

Ripple, W. J., J. A. Estes, R. L. Beschta, C. C. Wilmers, E. G. Ritchie, M. Hebblewhite, J. Berger, B. Elmhagen, M. Letnic, M. P. Nelson, et al., 2014. Status and ecological effects of the world's largest carnivores. Science 343:1241484.

Rosenzweig, M. L. \& R. D. McCord, 1991. Incumbent replacement: evidence for longterm evolutionary progress. Paleobiology Pp. 202-213. 
Roy, K., D. P. Balch, \& M. E. Hellberg, 2001. Spatial patterns of morphological diversity across the indo-pacific: analyses using strombid gastropods. Proc Biol Sci 268:2503-8.

Roy, K. \& M. Foote, 1997. Morphological approaches to measuring biodiversity. Trends in ecology \& evolution 12:277-281.

Rule, S., B. W. Brook, S. G. Haberle, C. S. Turney, A. P. Kershaw, \& C. N. Johnson, 2012. The aftermath of megafaunal extinction: ecosystem transformation in pleistocene australia. Science 335:1483-1486.

Safi, K., M. Cianciaruso, R. Loyola, D. Brito, A. Katrina, \& D. José, 2011. Understanding global patterns of mammalian functional and phylogenetic diversity. Philosophical transactions of the Royal Society of London. Series B, Biological sciences 366:25362544 .

Schemske, D., G. Mittelbach, H. Cornell, J. Sobel, \& K. Roy, 2009. Is there a latitudinal gradient in the importance of biotic interactions? Annu. Rev. Ecol. Evol. Syst. 40:245269.

Shepherd, U., 1998. A comparison of species diversity and morphological diversity across the north american latitudinal gradient. Journal of Biogeography 25:19-29.

Smith, F. A., J. H. Brown, J. P. Haskell, S. K. Lyons, J. Alroy, E. L. Charnov, T. Dayan, B. J. Enquist, S. M. Ernest, E. A. Hadly, et al., 2004. Similarity of mammalian body size across the taxonomic hierarchy and across space and time. The American Naturalist 163:672-691.

Smith, F. A. \& S. K. Lyons, 2011. How big should a mammal be? a macroecological look at mammalian body size over space and time. Philosophical Transactions of the Royal Society B: Biological Sciences 366:2364-2378.

, 2013. Animal body size: linking pattern and process across space, time, and taxonomic group. University of Chicago Press.

Smith, F. A., S. K. Lyons, S. M. Ernest, K. E. Jones, D. M. Kaufman, T. Dayan, P. A. Marquet, J. H. Brown, \& J. P. Haskell, 2003. Body mass of late quaternary mammals: Ecological archives e084-094 (updated version). Ecology 84:3403-3403.

Springer, M. S., R. W. Meredith, J. E. Janecka, \& W. J. Murphy, 2011. The historical biogeography of mammalia. Philos Trans R Soc Lond B Biol Sci 366:2478-502.

Terborgh, J. W. \& J. Faaborg, 1980. Saturation of bird communities in the west indies. American Naturalist Pp. 178-195.

Udvardy, M. D., 1975. A classification of the biogeographical provinces of the world, vol. 8. International Union for Conservation of Nature and Natural Resources Morges, Switzerland.

Vellend, M., 2010. Conceptual synthesis in community ecology. The Quarterly review of biology 85:183-206. 
Villalobos, F. \& H. T. Arita, 2014. Morphological diversity at different spatial scales in a neotropical bat assemblage. Oecologia 176:557-68.

Wallace, A., 1876. The geographical Distribution of Animals. Cambridge University Press.

Weiher, E. \& P. Keddy, 2001. Ecological assembly rules: perspectives, advances, retreats. Cambridge University Press.

White, E. P., S. K. M. Ernest, A. J. Kerkhoff, \& B. J. Enquist, 2007. Relationships between body size and abundance in ecology. Trends Ecol Evol 22:323-30.

Wiens, J. \& M. Donoghue, 2004. Historical biogeography, ecology and species richness. Trends in ecology \& evolution 19:639-644.

Wiens, J. J., 2011. The niche, biogeography and species interactions. Philos Trans R Soc Lond B Biol Sci 366:2336-50.

Wilf, P., N. R. Cúneo, I. H. Escapa, D. Pol, \& M. O. Woodburne, 2013. Splendid and seldom isolated: the paleobiogeography of patagonia. Annual Review of Earth and Planetary Sciences 41:561.

Wilman, H., J. Belmaker, J. Simpson, C. de la Rosa, M. M. Rivadeneira, \& W. Jetz, 2014. Eltontraits 1.0: Species-level foraging attributes of the world's birds and mammals: Ecological archives e095-178. Ecology 95:2027-2027.

Wilson, D. E. \& D. Reeder, 2011. Class mammalia linnaeus, 1758. Zootaxa P. 56.

Woinarski, J. C. Z., A. A. Burbidge, \& P. L. Harrison, 2015. Ongoing unraveling of a continental fauna: Decline and extinction of australian mammals since european settlement. Proc Natl Acad Sci U S A 112:4531-40.

Woodburne, M. O., 2010. The great american biotic interchange: dispersals, tectonics, climate, sea level and holding pens. Journal of Mammalian Evolution 17:245-264. 